\title{
8. SEDIMENTOLOGY, PHENOCRYST CHEMISTRY, AND AGE-MIOCENE "BLUE TUFF": SITES 794 AND 796, JAPAN SEA ${ }^{1}$
}

\author{
David A. Barnes, ${ }^{2}$ Peter Thy, ${ }^{3}$ and Paul Renne ${ }^{4}$
}

\begin{abstract}
Distinctive, massive to stratified, pale blue volcaniclastics, initially referred to as the "blue tuff," were encountered at all four sites drilled during ODP Leg 127 in the Japan Sea. Detailed vertical sequence analysis, plagioclase chemistry, plagioclase ${ }^{87} \mathrm{Sr} /{ }^{86} \mathrm{Sr}$ isotopic composition, and ${ }^{40} \mathrm{Ar}{ }^{39} \mathrm{Ar}$ age dating indicate that thick sequences of the blue tuff are not genetically related.

Blue tuffs at Hole 794B were apparently deposited by density flows at ambient temperature. Deposition was penecontemporaneous with a large submarine phreatomagmatic eruption at $14.9 \mathrm{Ma}$ in bathyal or deeper water depths. The blue tuffs at this location comprise mostly reworked hydroclastic glass shards and lesser amounts of plagioclase crystals. Pyrogenic plagioclase has an average An mole\% of $18 \pm 3$. Comparison of blue tuff plagioclase compositions with the composition of plagioclase from acoustic basement at Site 794 suggests that these rocks are not genetically related. As such, the extrapolation of sediment accumulation rate data in conjunction with this more precise age for the blue tuff corroborates previous minimum age estimates of $16.2 \mathrm{Ma}$ for acoustic basement at Site 794 .

Blue tuffs at Hole 796B were probably deposited at ambient temperatures by downslope slumping and density flow of reworked pyrogenic debris. This debris includes abundant bubble wall glass shards and plagioclase crystals, with variable admixture of volcanic lithic and intrabasinal fragments. Pyrogenic fragments were produced by subaerial or shallow submarine, magmatic eruptions dated at 7.6 Ma. Blue tuffs contain a heterogeneous mixture of unrelated fragments including a mixed population of plagioclase crystals. The average An mole\% of the predominant, probable comagmatic, plagioclase population is $30 \pm 4$.

The two sequences of blue tuff studied are distinct in age, mineral composition, and the eruptive origin of pyroclastic fragments. Preliminary ${ }^{87} \mathrm{Sr} /{ }^{86} \mathrm{Sr}$ isotopic compositions of plagioclase, however, indicates that blue tuffs at both locations are the product of typical, subduction-related island arc magmatism. Based on the results of this study, there is no justification for stratigraphic correlation of widespread, Miocene, blue to blue-gray bentonitic tuff and tuffaceous sandstones nor the interpretation that these strata are indicative of regional, explosive submarine volcanism genetically related to rifting and formation of the Japan Sea. Rather, these reworked pyroclastic strata of intermediate composition were deposited over a protracted 6-8 m.y. period in association with widespread, subduction-related submarine to subaerial volcanism in the Japan Sea backarc basin.
\end{abstract}

\section{INTRODUCTION}

Miocene strata informally called the "blue tuff" were recovered from all sites during Ocean Drilling Program Leg 127 in the Japan Sea (Figs. 1 and 2). At Sites 794 and 796 (over $300 \mathrm{~km}$ apart) these strata comprise lithologically distinctive, massive to stratified, pale blue to medium pale gray volcaniclastics that were initially described as primary submarine, vitric- and crystal-rich pyroclastic deposits (Tamaki, Pisciotto, Allan, et al., 1990). At all Leg 127 sites blue tuffs are the dominant lithic type. They range from less than $1 \mathrm{~m}$ to over $11 \mathrm{~m}$ in thickness. The characteristic blue color and thick bedding as well as consistent occurrence within a regionally recognizable calcareous and siliceous claystone lithofacies (Unit D of Tamaki, Pisciotto, Allan, et al., 1990; Fig. 2) initially suggested lithostratigraphic correlation of these blue tuffs.

Preliminary analysis (Tamaki, Pisciotto, Allan, et al., 1990) suggested that the pyroclastic material comprising the blue tuffs was admixed with intrabasinal debris during a regionally significant period of mafic to intermediate explosive submarine volcanism. Epiclastic debris was not identified in the blue tuffs, suggesting that Leg 127 drilling sites were isolated from subaerially exposed land masses. Strata associated with blue tuffs ranges in age from early Miocene (at Site 797) to middle Miocene (at Site 794) and possibly late Miocene (in Site 796) (Tamaki, Pisciotto, Allan, et al., 1990).

' Pisciotto, K. A.. Ingle, J. C., Jr., von Breymann, M. T., Barron, J., et al., 1992. Proc, ODP, Sci. Results, 127/128, Pt. 1: College Station, TX (Ocean Drilling Program).

${ }^{2}$ Department of Geology, Western Michigan University, Kalamazoo, MI 49008. U.S.A.

${ }^{3}$ Department of Geology, University of Botswana, Private Bag 0022, Bagarone, Botswana.

Institute of Human Origins Geochemistry Center, 2453 Ridge Road, Berkeley, CA 94709, U.S.A
The stratigraphic proximity of blue tuffs to subjacent mafic extrusive and intrusive rocks that constitute acoustic basement in the Yamato and Japan basins could indicate magmatic cogenesis. If this basement igneous complex formed during a period of intense, early to middle Miocene magmatic activity that was genetically related to rifting and subsequent subsidence in the Japan Sea region (Tamaki, Pisciotto, Allan, et al., 1990), then blue tuffs might also be related to rifting. This purported genetic relationship between rift-related volcanism and widespread blue tuff deposition would support diachronous rifting during the tectonic evolution of the Japan Sea region.

We first address the validity of correlation of blue tuff sequences based on the comparison of sedimentologic and petrologic characteristics. We also studied the megascopic and microscopic structures and textures, and the major element chemistry, isotope chemistry, and radiometric ages of pyrogenic fragments in order to interpret the emplacement mechanisms, depositional setting, and the petrologic affinity of the blue tuffs. Our results define the general magma type and the paleogeography during emplacement of the blue tuffs and their relationship to the voluminous volcanic rocks purportedly formed during the rifting and formation of the Yamato and Japan basins (Tamaki, Pisciotto, Allan, et al., 1990).

\section{METHODS AND MATERIALS}

\section{Sedimentology}

Thick-bedded, coarse-grained intervals of blue tuff are best represented in cores drilled at Sites 794 and 796 located in the northern Yamato and Japan basins, respectively (Fig. 1). Traditional, sedimentologic vertical sequence analysis of volcaniclastic rocks is useful for interpreting the conditions during magmatism and deposition (Cass and Wright, 1987). Detailed description of intervals dominated by blue tuffs were compiled from cores taken in Sites 794 and 796. These descriptions include sedimentary structures, grain-size variation, and lithology. Eruptive mechanisms and the environmental conditions 


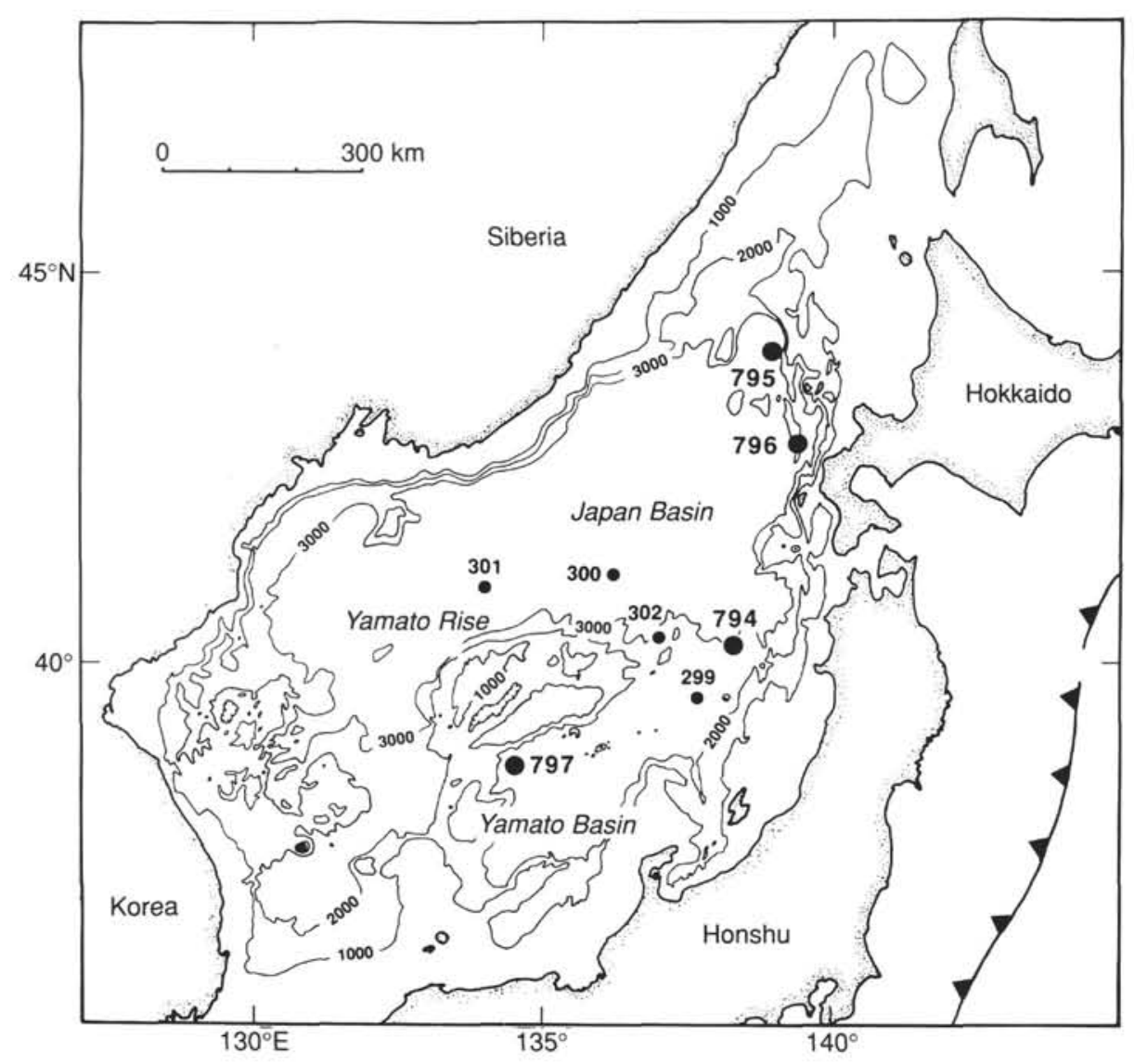

Figure 1. Location map showing ODP Leg 127 (large dots) and DSDP Leg 31 (small dots) drilling sites in the Japan Sea.

during deposition of the tuffaceous units were interpreted based on these observations in conjunction with the analysis of petrographic microtextures observed in thin section.

\section{Pyrogenic Crystal Chemistry}

Although lavas and intrusive rocks in submarine volcanic successions are commonly hydrothermally altered, the pyrogenic crystal component of associated tuffaceous strata may escape the effects of such alteration. The major element chemistry, isotope chemistry, and absolute age of unaltered, pyrogenic minerals in tuffs provides information for the interpretation of magmatism that is not otherwise available. The major element chemistry of plagioclase in blue tuffs and related strata in Sites 794 and 796 was analyzed initially to evaluate the homogeneity of fragmental particles in individual samples. Isotopic analysis of plagioclase crystal fractions from individual samples is relevant only if these samples contain a homogeneous crystal fraction and are, therefore, considered cogenetic, juvenile crystal ejecta. Wavelength-dispersive, electron probe microanalysis (EPMA) was used to determine the major element composition on polished thin sections or grain mounts of crystal separates from poorly consolidated samples. Six samples were analyzed from Site 794, Hole B, and 13 were analyzed from Site 796, Hole B. Data were generated by microprobes in two laboratories (accelerating voltages: $12 \mathrm{kV}, 15 \mathrm{kV}$; focused beam approximately $10 \mu \mathrm{m}$; beam currents: $7 \mathrm{nA}$ and $25 \mathrm{nA}$; respectively). Although some inconsistency was recognized in the data generated from the two labs, clustering amongst related samples was clearly recognizable in the combined data sets.

\section{${ }^{40} \mathrm{Ar} /{ }^{39} \mathrm{Ar}$ Dating}

Glassy fragments in tuffs are ubiquitously replaced by alteration products so that neither the chemistry of glass nor whole-rock chemical analyses are pertinent to the interpretation of magma genesis. The age of volcanism and tectonic activity represented by blue tuffs in the Japan Sea region was investigated using the ${ }^{40} \mathrm{Ar} /{ }^{39} \mathrm{Ar}$ dating technique on plagioclase, hornblende, and biotite grains separated from appropriate samples. The friable, clay-rich, tuffaceous rocks were easily disaggregated by gentle crushing and ultrasonic agitation.

Hand-picked grains from the 200- to $500-\mu \mathrm{m}$ size fraction were rinsed in $10 \% \mathrm{HCl}$, followed by $7 \% \mathrm{HF}$, for $5 \mathrm{~min}$ each in an ultrasonic bath. Grains were selected to be free of visible alteration, inclusions, or adhering material. Ten to 30 grains from each sample were loaded into cylindrical pits in an $\mathrm{Al}$ disk along with grains of Fish Canyon sanidine (Cebula et al., 1986), which was used as a neutron flux monitor. Samples were submitted to the Omega West reactor at Los Alamos National Laboratory for a $30 \mathrm{~min}$ irradiation, but they were irradiated for approximately $29 \mathrm{hr}$ due to an error at the reactor facility.

All samples were analyzed by total fusion on the IHOGC automated ${ }^{40} \mathrm{Ar}{ }^{39} \mathrm{Ar}$ laser microprobe using procedures similar to those detailed by Deino and Potts (1990) and Renne et al. (1991). Gas was purified for $200 \mathrm{~s}$ with two $\mathrm{Zr}-\mathrm{Fe}-\mathrm{V}$ getters run at $3.0 \mathrm{amp}$. System blanks were analyzed between every three samples, and interpolated values used to correct the sample data.

Ten aliquots of purified atmospheric Ar from an automated pipette system were run over the course of the sample analysis, yielding a 
mean ${ }^{40} \mathrm{Ar} /{ }^{36} \mathrm{Ar}$ of $288.42 \pm 3.01$ (sigma) corresponding to mass discrimination of $1.0061 \pm 0.0026$ (sigma) per mass unit with reference to atmospheric ${ }^{40} \mathrm{Ar} /{ }^{36} \mathrm{Ar}=295.5$ (Nier, 1950). Five grains of Fish Canyon sanidine from the 590- to $840-\mu \mathrm{m}$ fraction were analyzed individually to yield a J-value of $2.8634 \times 10^{-2} \pm 3.34 \times 10^{-5}$ based on an age of $27.84 \mathrm{Ma}$.

\section{${ }^{87} \mathrm{Sr} /{ }^{86} \mathrm{Sr}$ Isotopic Composition}

A split of crystal residues was also provided for isotopic analysis of ${ }^{87} \mathrm{Sr} /{ }^{86} \mathrm{Sr}$ ratios in plagioclase to interpret source magma affinities. The plagioclase crystal separates were purified by magnetic separation, handpicked for visual homogeneity, and ultrasonically agitated to remove adhered material. The samples were then washed in warm $\left(\sim 50^{\circ} \mathrm{C}\right) 2.5 \mathrm{M}$ $\mathrm{HCl}$ to further clean the surfaces before dissolution. Chemical processing consisted of dissolution in $\mathrm{HF}$ and $\mathrm{HClO}_{4}$ followed by cation-exchange separation of Sr using Dowex 50 resin. Isotope analysis were made with a Finnigan MAT 261 mass spectrometer operated in the static mode. The ${ }^{87} \mathrm{Sr} /{ }^{86} \mathrm{Sr}$ ratios were normalized within a run to ${ }^{86} \mathrm{Sr} /{ }^{88} \mathrm{Sr}=0.119400$, and further adjusted to a value of 0.710200 for the NBS-987 interlaboratory reference standard.

\section{SEDIMENTOLOGY OF VOLCANICLASTICS}

Graphic representation of two sections of blue tuffs described from Sites 794 and 796 are presented in Figures 3A and B (respectively). Each sequence contains distinct, blue to blue-gray beds of coarse-grained volcaniclastics defined by sharp, scoured bases, well-defined internal, planar lamination, and complex, internal size grading. These beds are interstratified with laminated to burrowed, diatomaceous and calcareous, hemipelagic claystone. Intraformational claystone rip-up clasts to several centimeters are common in the thicker, coarser-grained beds.

\section{Blue Tuffs in Site 794, Hole B}

Volcaniclastic strata a few decimeters to several meters thick in Cores 127-794B-21R through 127-794B-23R occur in eight discrete units defined by sharp, commonly scoured basal contacts (Fig. 3A). The base of units 3 and 5 contain pronounced inverse to normal (symmetrical) size grading. The massive, unstratified basal portions of these units are gradational upward to well developed planar stratification and then to convolute lamination and bioturbation at the top. Abundant, intraformational rip-up clasts of siliceous claystone occur at the base of the massive and structureless units. Elongate rip-up clasts are aligned parallel to bedding in the basal portion of unit 3 . These clasts are randomly oriented higher in this unit and are, again, horizontally aligned at the top of the massive portion of the unit. Horizontal clast alignment is common throughout unit 5 . The uppermost portions of these thick units are bioturbated and gradational to overlying claystone and silty claystone. The maximum grain size within these thickly bedded units is $10-20 \mathrm{~mm}$ and size sorting is generally poor.

Planar bedding is pronounced in the upper portion of the thick units and is defined by interstratified layers that are alternately dominated (on a decimeter scale) by low-density tube pumice and then more dense, vesicular, vitric hydroclasts and/or plagioclase crystals (see the following petrographic descriptions). Adjacent layers that contain clasts of predominantly different density are not clearly gradational, however. The basal, massive portion of unit 3 contains a substantial crystal component, up to $10 \%$. These crystals are also irregularly distributed, in lesser proportions, in the upper, strongly planar laminated layers of this unit. The upper part of unit 5 contains only a trace of plagioclase crystals. Overall, dense, slightly vesicular hydroclasts and plagioclase crystals are more abundant at the base of these thick units whereas less dense, tube pumice is more abundant at the top. These relationships are interpreted as crude density grading in the massive beds.
Thinner bedded units 1 and 2 (Fig. 3A) at the base of the sequence are disrupted by drilling. They contain mostly coarse-grained, slightly vesicular hydroclasts and plagioclase crystals and were apparently truncated as a result of the emplacement of subsequent layers. Finer grained and thinner bedded units higher in the section (units 4, 6, 7, and 8; Fig. 3A) contain better preserved structures and are characterized by fine- to very-fine-grained beds that overly sharp, scoured contacts with underlying beds. Normal size grading is vague to distinct. The upper parts of these beds grades into overlying claystone. Backfilled burrows are common in the upper, finer grained parts of these beds and are both horizontally and obliquely oriented. Deformational structures are common including flames, and convolute laminations.

\section{Blue Tuffs in Site 796, Hole B}

Coarse-grained Miocene volcaniclastics occur within lithofacies D (Tamaki, Pisciotto, Allan, et al., 1990) at Site 796 in the eastern Japan Basin (Fig. 1). The succession of pale blue to blue-gray volcaniclastics consists of seven distinct units identified by sharp, scoured basal contacts, complex size and density grading, and planar bedding (Fig. 3B). The grain size ranges from rare granule- $(3-4 \mathrm{~cm})$ size fragments (mainly intraformational siliceous mudstone rip-up clasts) to very-fine-grained ash. These units are interbedded with bioturbated, hemipelagic, siliceous claystone.

The thickest unit (unit 2; Fig. 3B) is approximately $2.6 \mathrm{~m}$ thick and is characterized by sharp basal scour, a thin zone of inverse size grading, and abundant intraformational rip-up clasts. The upper portion of this unit contains gradational contacts between individual, normal-sizegraded, centimeter- to decimeter-thick layers with pronounced planar bedding megascopically defined by color banding (PI. 1, Fig. 1). Color banding is due to gradational variation in grain composition from darkcolored, lithic- and crystal-rich layers below to lighter colored, vitric-rich layers above. Thinner, normal-size-graded layers in the section are also color banded as a result of crystal and lithic fragment concentration relative to the vitric components (PI. 1, Fig. 2).

Particle size sorting in the sequence is moderate to poor within inversely and normally graded units, although the density segregation of the particles is moderately well developed. The basal portions of all units are dominated by denser particles including lithic fragments, plagioclase, and minor amphibole crystals. The upper, complexly size-graded portion of unit 2 contains density-segregated layers with gradational contacts within the overall fining-upward interval. These structures indicate amalgamation of density flows deposited in rapid succession.

\section{Petrography of Blue Tuffs: Site 794, Hole B}

The composition of clasts in blue tuffs at Site 794 was determined by examination of 20 thin sections and is generally uniform through the section. Abundant long-tube pumice (PI. 2, Fig. 1) and shards show no evidence of pre- or syndepositional physical/chemical alteration. These fragment types, along with abundant euhedral or broken euhedral plagioclase crystals, are a good indication of a pyrogenic origin and attest to contemporaneous, active volcanism (Fiske, 1969). Long-tube pumice is, in general, most common in proximal, subaqueous pyroclastic deposits because of its greater permeability and susceptibility to water saturation and rapid sinking (Fiske, 1969). Long-tube pumice is more common at the top of thick units of blue tuffs and was apparently less dense than the crystal component. Long-tube pumice is present in smaller proportions than other vitroclasts throughout the sequence in Cores 127-794B-21R through 127-794B-23R.

Vesicular glass shards with spherical vesicles are the major vitroclastic constituent of tuffaceous rocks (Pl. 2, Fig. 2). These vitric fragments are characterized by equant shapes and sharp, arcuate boundaries that commonly transect vesicles. Vesicle size, as indicated by the radius of curvature of partial vesicles, is commonly less than the size of the vitric fragments ( $\mathrm{Pl}$. 2, Fig 3 ). Original void space is typically less than $30 \%-50 \%$. Vitroclastic particles of this shape have 


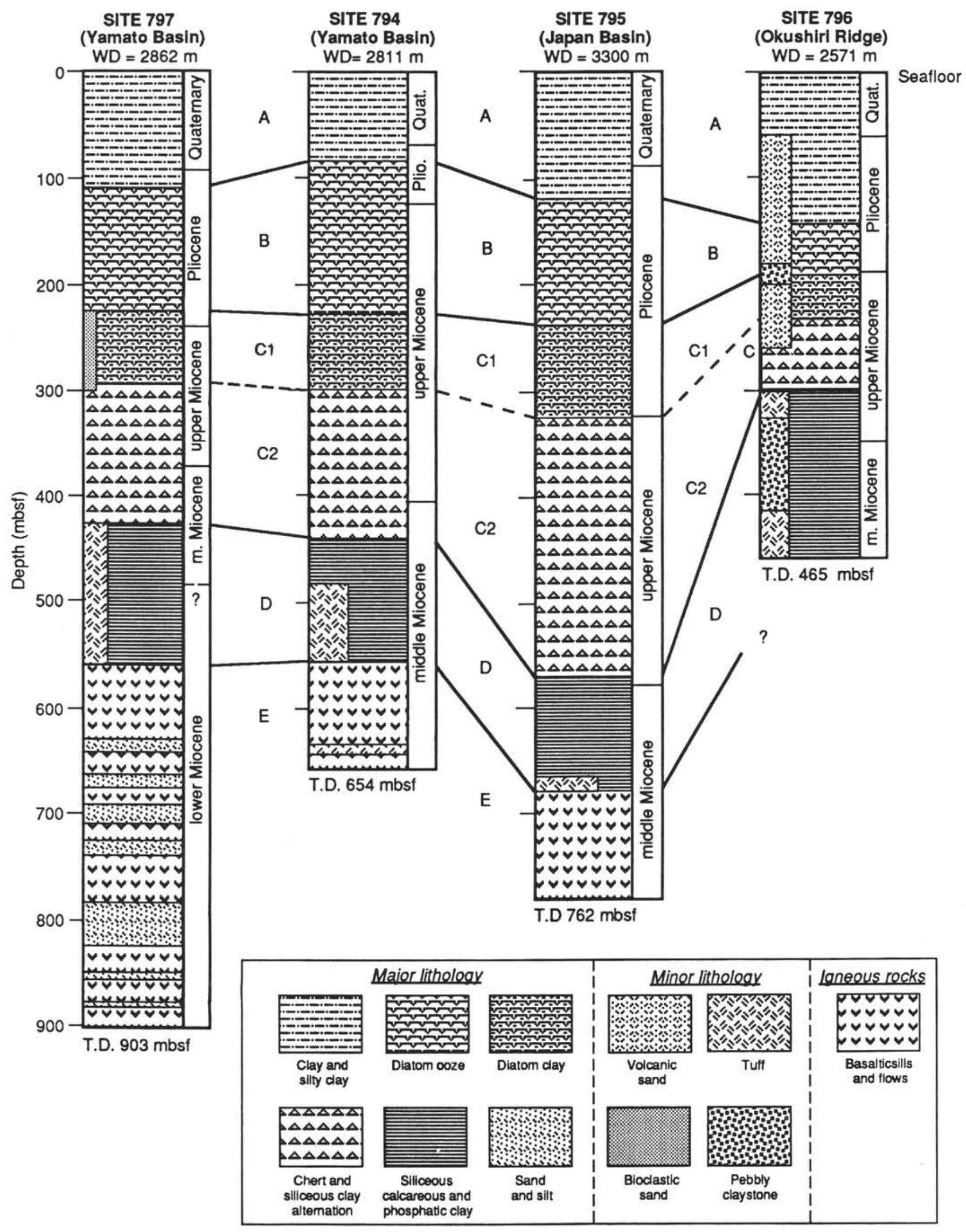

Figure 2. Stratigraphy at Leg 127 drill sites (from Tamaki, Pisciotto, Allan, et al., 1990). 
been ascribed to hydroclastic eruption by Heiken (1972). Subsequent work by Wohletz (1983), however, has shown that the distinction of blocky shards as the unique product of phreatomagmatic eruptions may be too simplistic (Cass and Wright, 1987).

Vesicular hydroclasts in subaqueous pyroclastic successions have been interpreted to result from eruptions above the pressure compensation level (PCL, the depth at which magma vapor pressure exceeds water pressure; Fisher, 1984). This depth is a function of the depth of the water column and the volatile composition of the magma. This depth may exceed $1000 \mathrm{~m}$ for volatile-rich alkalic magmas (Fisher, 1984). Preliminary results of the petrologic affinities of sills recovered in the basement complex at Site 794 (Tamaki, Pisciotto, Alan, et al., 1990) suggest a moderate to very low magmatic water content for these magmas. Such lavas, if they are related to the blue tuffs, might be expected to have a moderate to shallow $(<1000 \mathrm{~m})$ PCL. Recent observations from the Izu-Bonin Island arc (Gill et al., 1990) suggest that the PCL of backarc basin basalts can be deeper than $2000 \mathrm{~m}$ and result in explosive hydroclastic eruptions at this depth.

The proportions of vitric fragments and plagioclase crystals in blue tuffs varies irregularly through the sequence as a result of complex density segregation (see the preceding). All originally vitric-rich fragments are now altered to a uniform greenish brown, translucent, and slightly birefringent alteration product resembling palagonite. This material is composed predominantly of dioctahedral smectite (on the basis of preliminary $\mathrm{X}$-ray diffractograms of clay separates). Euhedral and broken euhedral plagioclase crystals are also common pyrogenic fragments but comprise no more than $10 \%$ of any sample (Pl. 2, Fig. 4). Rip-up clasts of intraformational, siliceous claystone and disseminated claystone are the only other significant components of the tuffaceous strata.

\section{Petrography of Blue Tuffs: Site 796, Hole B}

Eleven thin sections were examined to determine the composition and textures of volcaniclastics in Core 127-796B-18R. The composition of these strata is more heterogeneous, compared to blue tuffs at Site 794 , and includes abundant $(20 \%-40 \%)$ nonvolcanic material in some samples. Most nonvolcanic material consists of intraformational siliceous claystone clasts and a disseminated, microfossiliferous matrix. Rare green grains, probably glauconitic, are also present.

The dominant component in most tuffaceous strata is an interparticle "paste" now altered to moderate birefringence clay. X-ray diffraction analysis of clay-size separates indicates that this clay is dioctahedral smectite. However, the clast composition of any sample varies as a function of position within flow units (see the preceding description of density segregation). Indistinct portions of the clay-rich matrix retain altered intersertal textures with plagioclase microphenocrysts clearly indicating a volcanic, lithic-fragment origin. Other areas in the matrix contain indistinct clasts with possible long-tube pumice texture, although most of the matrix is probably altered fine-grained ash.

Discrete bubble-wall glass shards are also a major component of blue tuff at Site 796 and comprise between $10 \%$ and $30 \%$ of most samples. Shards are present throughout the section, but are concentrated in the upper portions of all flow units as a result of density segregation. Shards are ubiquitously altered to lath-shaped zeolite, identified as clinoptilolite-heulandite group minerals (on the basis of preliminary X-ray-diffraction analyses). The shard morphology is well preserved with consistent bubble wall shape having common cuspate junctions and a large vesicle size compared with fragment size (as determined by the radius of curvature of partial vesicles; Pl. 2, Fig. 5). Bubble wall shards are typically interpreted as the product of explosive vesiculation during magmatic eruption without substantial influence of water interaction with the melt (Heiken, 1972, 1974).

The basal portions of most units in Core 127-796B-18R are pyrogenic crystal rich $(10 \%-30 \%)$ including abundant plagioclase, minor amphibole, and trace biotite and quartz. Most crystals are euhedral or euhedral and broken (Pl. 2, Fig. 6). Individual thin units in the sequence typically contain concentrations of crystals and intermediate volcanic lithic fragments at their base, although unit 2 contains complex size and density grading in the upper, planar-bedded portion (Pl. 1, Fig. 1). Both size and density grading throughout the blue tuff and especially in unit 2 indicate multiple, density flows and complex amalgamation. The abundance of lower density vitric particles, compared with more dense crystal and lithic particles, has apparently resulted in the unusual (compared with typical epiclastic density flow deposits) size and density grading in the unit.

\section{Depositional Mechanisms: Site 794, Hole B}

Blue tuffs at Site 794 are interbedded with fossiliferous hemipelagic mudstone deposited in middle bathyal depths (Tamaki, Pisciotto, Allan, et al., 1990). Abundant long-tube pumice and moderately vesicular, blocky shards suggest a hydroclastic origin for these tuffaceous strata in association with a subaqueous phreatomagmatic eruption at Site 794. The overall symmetrically (inverse to normal) graded, thick units 3 and 5 are interpreted as single submarine density-flow events followed, in abrupt succession by smaller flow pulses defined by density grading in the planar-bedded upper portion of these units. The lower, massive portions of units 3 and 5 is unusually thick ( $>60 \%$ of the entire beds) compared to typical, coarse-grained epiclastic density flow deposits and are overlain by planar-bedded and indistinctly density-graded layers. These features suggest a subaqueous pyroclastic flow origin wherein the overall upward-fining grain size of the thick flow units resulted from the waning force of a contemporaneous, subaqueous eruption (Fiske and Matsuda, 1964; Fisher, 1984; Fisher and Schmincke, 1984). The separation of individual flow units by marine claystone layers reflects periods of quiescence and suspension sedimentation between eruptive events.

Recent findings regarding the PCL (Fisher, 1984) for magmatic water-rich, backarc basin basalts (Gill et al., 1990) indicate that vesicular hydroclasts do not clearly constrain the maximum depth of explosive, submarine phreatomagmatic eruptions. Backarc spreading center basalts and associated basalt breccia clasts in the Izu-Bonin arc are observed to contain vesicles caused by explosive eruption at emplacement depths greater than $1800 \mathrm{~m}$ (Gill et al., 1990). As such, there are no unequivocal indications of paleobathymetry that can be interpreted from vesicular submarine, pyroclastic flow deposits of the blue tuff at Site 794.

\section{Depositional Mechanisms: Site 796, Hole B}

Abundant bubble wall shards in blue tuffs at Site 796 suggest that this pyroclastic debris may have originated as a result of explosive vesiculation and pyroclastic transport during a large magmatic eruption. Bubble wall shard texture is in strong contrast to the common hydroclasts of apparent phreatomagmatic eruption origin in blue tuffs at Site 794. The pyroclastic debris in Core 127-796B-18R was probably generated by subaerial or shallow subaqueous eruptions, deposited in marine waters, and subsequently remobilized by density flow. Density flows were probably generated by slumping on over-steepened slopes adjacent to the magmatic centers although a considerable distance of pyroclastic transport may have preceded marine deposition and subsequent downslope remobilization. There is no clear indication of penecontemporaneous density transport of blue tuffs at Site 796 following the magmatic eruptions that produced the tuffaceous debris. These units may have been emplaced by density-flow mechanisms that were essentially unrelated to the eruption that formed the majority of the tuffaceous detritus. The depositional mechanism responsible for complexly graded units composed of reworked, dominantly pyroclastic material and emplaced by epiclastic slumping and density flow is a poorly documented but typical aspect of marine deposits associated with marginal basin volcanism (Fisher, 1984). 


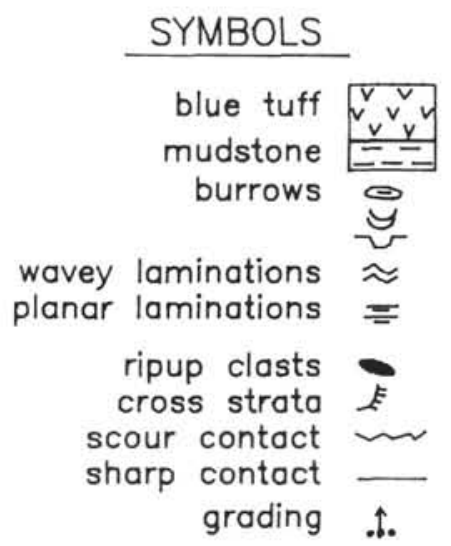

A
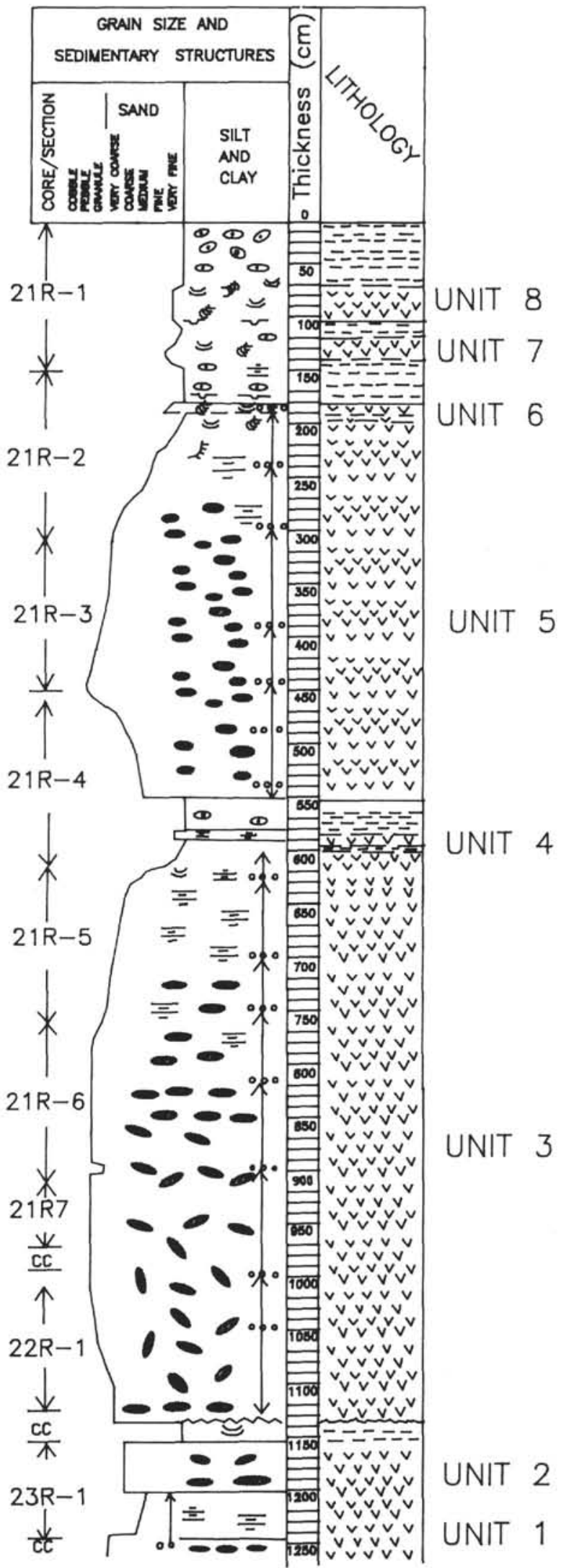

Figure 3. Graphic representation of the blue tuff. A. Cores 127-794B-21R through 127-794B-23R. B. Core 127-796B-18R. 


\section{SYMBOLS}

\section{blue tuff \\ mudstone burrows}

wavey laminations planar laminations

ripup clasts cross strata scour contact sharp contact grading
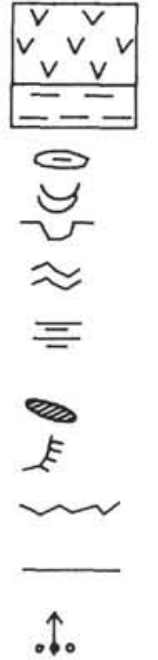

\section{B}

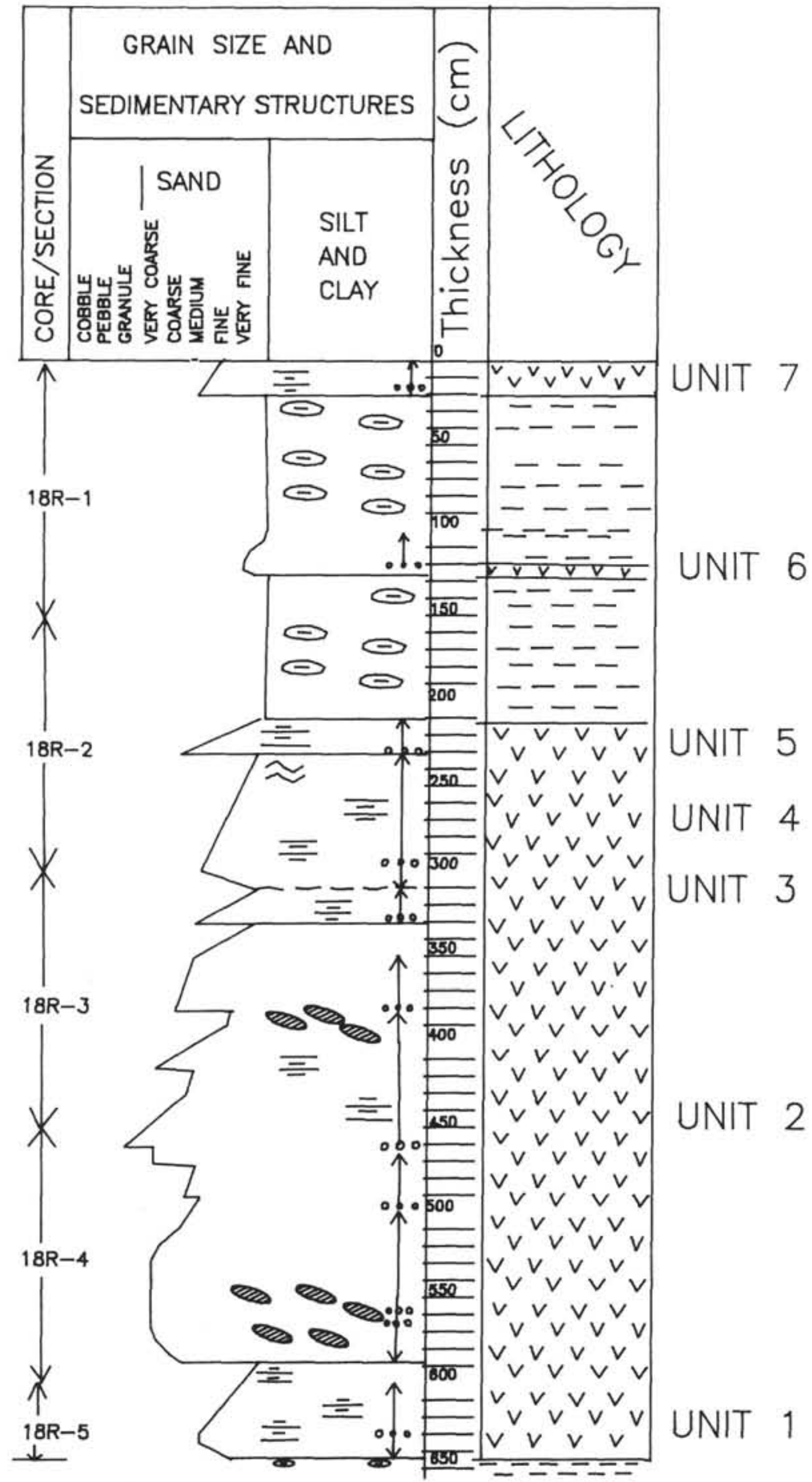

Figure 3 (continued).

\section{PETROGENESIS}

\section{Pyrogenic Crystal Chemistry}

The composition of pyrogenic plagioclase crystals in blue tuffs at both Sites 794 and 796 was investigated using the EPMA. In samples with relatively homogeneous plagioclase feldspar compositions these feldspars are interpreted as cogenetic, juvenile crystal ejecta. The composition of these cogenetic plagioclase may then be interpreted in terms of the general magma type. Cogenesis of plagioclase grains in individual samples is a prerequisite for the use of other analytical techniques, including ${ }^{40} \mathrm{Ar} /{ }^{39} \mathrm{Ar}$ dating and ${ }^{87} \mathrm{Sr} /{ }^{86} \mathrm{Sr}$ analysis, to interpret the origin of blue tuffs.

EPMA analysis of 6-19 individual crystals in 19 tuffaceous samples is reported in Table 1. Most of the analyses are from plagioclase in blue tuffs although plagioclase in several additional samples of coarse-grained tuffaceous sandstone from Site 796 were also analyzed.

The variation in An mole\% of plagioclase crystals from Site 794 is indicated in Figure 4A. The mean An mole\% for plagioclase from blue tuffs at this site is $18 \pm 3$. Because low-temperature alteration of plagioclase feldspar normally results in nearly pure albitic phases (Boles, 1982) these plagioclase are probably not significantly altered 
A

Anorthite mole\%

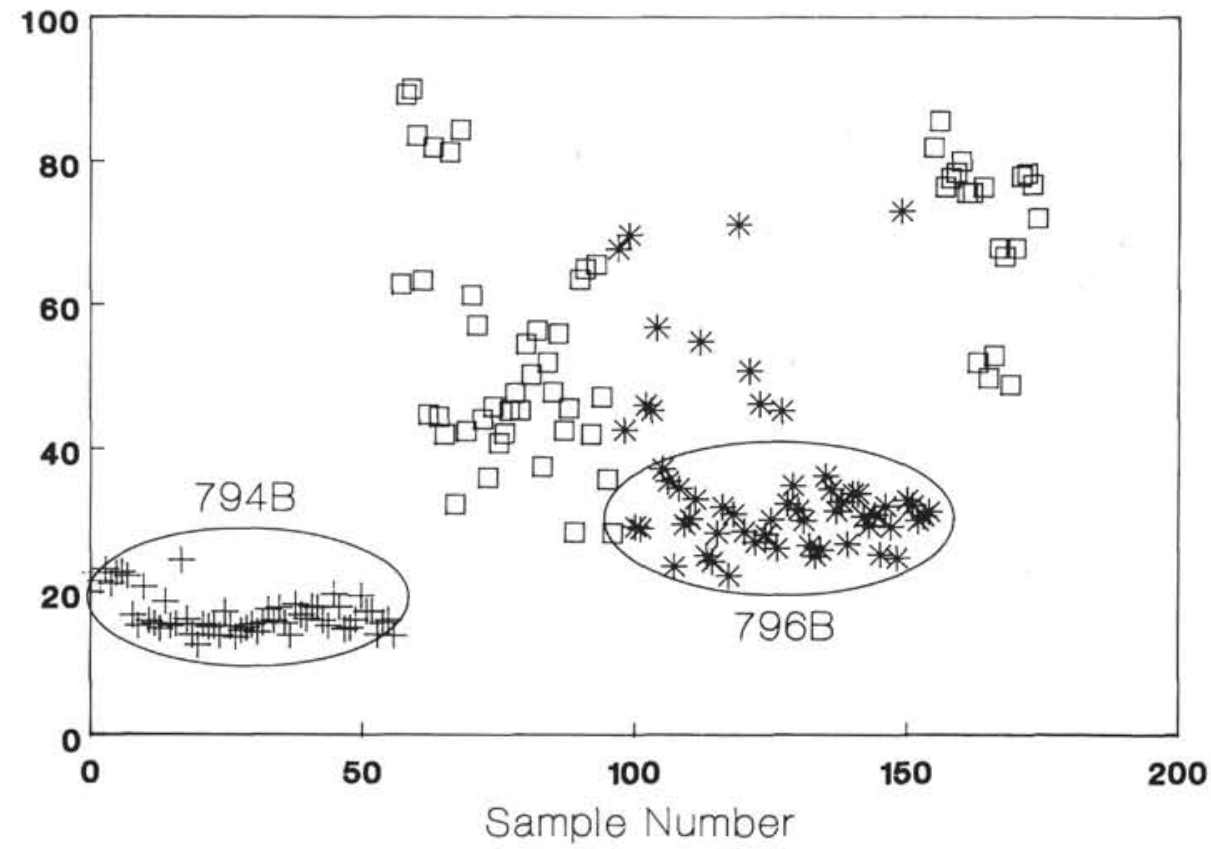

B

Anorthite mole\%

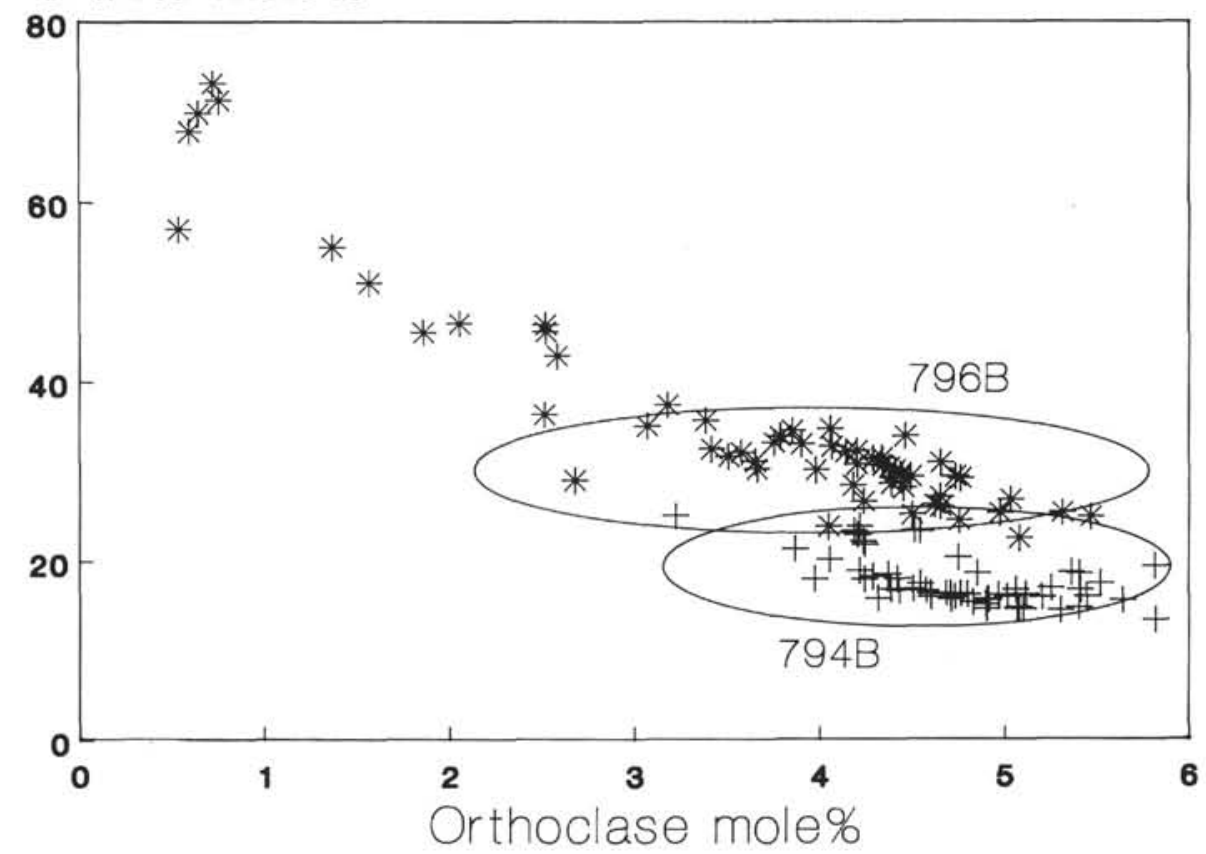

Figure 4. A. Anorthite mole\% for all samples vs. sample number (Table 1). Sample numbers in Table 1 are arranged from top to base in each site. Crosses and stars are samples from blue tuffs at Sites 794 and 796, respectively. Boxes are non-blue tuff samples at Site 796. The circled fields indicate the interpreted cogenetic plagioclase from blue tuffs at both sites. B. Orthoclase mole\% vs. anorthite mole\% for blue tuff samples. The circled fields indicate interpreted cogenetic plagioclase from blue tuffs at Sites 794 and 796. Data from Table 1. Symbols as in A. 
by diagenesis. Figure 4B also suggests relative homogeneity of the plagioclase crystal component in blue tuffs at Site 794 .

Considerable scatter exits for all other samples analyzed from Site 796, including blue tuffs in Core 127-796B-18R (Fig. 4A). The plagioclase in blue tuffs at Site 796 have mean An mole\% of $36 \pm 12$. This scatter in plagioclase composition is also represented in Figure 4B. A distinct crystal population can be defined, however, for plagioclase with An mole $\%<40$, low $\mathrm{Ca} / \mathrm{K}$ values $(<15)$, and moderately high $\mathrm{K}$ values $(>2.5 \%)$. The average An mole\% of these plagioclase is $30 \pm 4$. These plagioclases are the dominant, probably comagmatic, juvenile crystal ejecta component in blue tuffs in Site 796. Other plagioclase crystals are interpreted as detrital contamination or mixing of other unrelated pyroclastic material.

The compositions of plagioclase crystals in blue tuffs at Site 794 suggest little or no contamination of cogenetic, juvenile particles consistent with the sedimentologic interpretation that the blue tuff is a reworked but essentially uncontaminated pyroclastic deposit. The composition of plagioclase in Site 794 blue tuffs is sodium-rich $\left(A n_{15-24}\right)$ and is unlike the composition of feldspars in plagioclase phyric basalt recovered from acoustic basement in this site $\left(\mathrm{An}_{45-90}\right.$; Thy, this volume). The comparison of blue tuff and basement igneous complex plagioclase compositions at Site 794 suggests that these units are unrelated.

Considerable mixing of disparate plagioclase in blue tuffs is interpreted at Site 796. The dominant plagioclase population in Site 796 blue tuffs is more calcic in composition $\left(\mathrm{An}_{25-38}\right)$ with respect to the Site 794 blue tuff plagioclase but may constitute cogenetic, juvenile crystal ejecta. Site 796 blue tuffs contain a substantial component of reworked fragments, however, and are significantly adulterated by accidental or unrelated detrital components.

\section{Results of ${ }^{40} \mathrm{Ar} /{ }^{39} \mathrm{Ar}$ Dating: Site 794, Hole B}

Fifteen individual grains from two tuff samples in Site 794 (Table 2) yield dates that range between $12.65 \pm 0.82$ and $16.82 \pm 0.79 \mathrm{Ma}$. The individual grain dates appear normally distributed rather than multimodal, suggesting that xenocrystic contamination is not present. ${ }^{37} \mathrm{Ar} /{ }^{39} \mathrm{Ar}$ values for the plagioclase grains imply $\mathrm{Ca} / \mathrm{K}$ atomic ratios of 3.2-9.0, with all but one less than 6.7. This is in close agreement with the EPMA data (Table 1). Mean dates and standard errors of the mean for the two samples are $14.87 \pm 0.16$ and $14.85 \pm 0.18 \mathrm{Ma}$; the ages of the two units are therefore analytically indistinguishable based on the present data.

These radiometric ages for blue tuffs in Site 794 are geologically reasonable compared to the age indicated by biostratigraphic data presented in Tamaki, Pisciotto, Allan, et al. (1990). Biochronology and sediment-accumulation rate extrapolation indicates a middle Miocene (13-14 Ma) age for blue tuffs. Basement ages (Tamaki, Pisciotto, Allan, et al., 1990) at Site 794 range from 14.8 to $16.2 \mathrm{Ma}$, again, on the basis of biochronology and sediment-accumulation rate extrapolation. The deposition of blue tuffs at this site is interpreted here (see the preceding) as essentially contemporaneous with its magmatic origin at approximately $14.9 \mathrm{Ma}$ and suggests two possible interpretations. The first alternative is that the basement igneous complex at this site may be contemporaneous with eruption and emplacement of blue tuffs at 14.9 Ma. The second alternative is that basement rocks are unrelated to blue tuffs and the actual age of the basement at this site may be evaluated by sediment-accumulation rate extrapolation from the 14.9 Ma age of the blue tuff. This extrapolated age corroborates initial estimates of the minimum age for basement of 16.2 Ma (Tamaki, Pisciotto, Allan, et al., 1990). The dissimilarity in plagioclase composition in blue tuffs compared to basement sills and flows (see the preceding) tentatively favors the second interpretation presented here.

\section{Results of Dating: Site 796, Hole B}

Four grains of plagioclase from one sample at Site 796 were analyzed after preheating at $0.3 \mathrm{~W}$. Three grains (Table 2 ) yielded nearly concordant dates with a mean and standard error of $7.61 \pm 0.56 \mathrm{Ma}$. Ca/K for the three grains ranged from 6.4 to 6.6 consistent with EPMA data for interpreted comagmatic plagioclase (Table 1). The fourth plagioclase grain yielded a considerably younger date of $4.91 \pm 0.57 \mathrm{Ma}$ and had a slightly lower $\mathrm{Ca} / \mathrm{K}$ of 5.9. The two biotite grains were not preheated with the laser; these gave statistically indistinguishable dates of $5.15 \pm 0.28$ and $5.07 \pm 0.08 \mathrm{Ma}$, despite a significant difference in the extent of atmospheric contamination (see Table 2). These dates are also similar to that obtained from the anomalous plagioclase grain. Hornblende from Site 796 was analyzed by total fusion of 12 grains, resulting in a date of $9.79 \pm 0.50 \mathrm{Ma}$.

The significance of the limited data from Site 796 is uncertain. However, comparison with biostratigraphic data and the extrapolation of sediment-accumulation curves (Tamaki, Pisciotto, Allan, et al., 1990 ) indicates that the three older plagioclase grains date the maximum age of deposition of the tuff at $7.61 \pm 0.56 \mathrm{Ma}$ and the younger dates may reflect grain alteration. The apparent contemporaneity of ages in these younger grains would be fortuitous in this interpretation. Alternatively, the two biotite grains and the anomalously young plagioclase grain are cogenetic and the tuff is $5.05 \pm 0.31 \mathrm{Ma}$ based on the mean (and standard error) of the three grain dates. This is unlikely, however, in light of reliable diatom dates from nearly 100 $\mathrm{m}$ uphole of 6.4 Ma (Tamaki, Pisciotto, Allan, et al., 1990). In either case, the hornblende is likely to have been derived from reworking of one or more older sources. Further clarification of the age of this unit would require the analysis of many more grains in order to define the distribution of apparent ages, which would help distinguish between contamination and alteration to explain the data.

\section{${ }^{87} \mathrm{Sr} /{ }^{86} \mathrm{Sr}$ Isotopic Composition}

Observed ${ }^{87} \mathrm{Sr} /{ }^{86} \mathrm{Sr}$ measurements from plagioclase crystal separates were undertaken in order to infer the tectonic affinity of source magmas for blue tuffs from Sites 794 and 796. Values are presented in Table 3 and show a range from 0.704199 to 0.709547 for samples from both Sites 794 and 796. We believe that the analysis from Sample 127-794B-23RCC, $10-13 \mathrm{~cm}$, of 0.709547 may not be representative of the true strontium ratio in pyrogenic plagioclase but is a function of contamination by clay-rich matrix or the alteration of feldspar crystals. More analyses would be needed to verify this preliminary interpretation, however. We interpret all other samples to represent the true range of observed strontium isotope ratios for pyrogenic feldspars in the blue tuff from both sites (0.704512-0.704199).

The general homogeneity of strontium ratios from the samples suggests similar magmatic derivation in a plate tectonic context. The range of values for these samples is very close to the average value of 0.70437 for island arcs derived from the upper mantle (Faure, 1986).

\section{SUMMARY \\ Depositional Setting}

The deposition of Miocene blue tuff successions encountered at Sites 794 and 796 (Tamaki, Pisciotto, Allan, et al., 1990) was interpreted based on associated strata, sedimentary facies characteristics, and glass shard morphology. Blue tuffs at Site 794 are composed of juvenile pyroclasts and minor intraformational material apparently deposited by cool or cold density flows that formed contemporaneously with a large submarine phreatomagmatic eruption. The minimum water depth at the site of eruption is poorly constrained but was 
Table 1. Electron probe microanalysis of plagioclase from blue tuffs and related strata, Leg 127. Elemental data are presented as atomic fractions normalized to eight oxygens.

\begin{tabular}{|c|c|c|c|c|c|c|c|c|c|c|c|}
\hline $\begin{array}{l}\text { Analysis } \\
\text { no. }\end{array}$ & $\begin{array}{l}\text { Hole, section, } \\
\text { interval }(\mathrm{cm})\end{array}$ & $\mathrm{Si}$ & $\mathrm{Al}$ & $\mathrm{Fe}$ & $\mathrm{Ca}$ & $\mathrm{Na}$ & $\mathrm{K}$ & Total & $\begin{array}{l}\text { An } \\
(\%)\end{array}$ & $\begin{array}{l}\mathrm{Ab} \\
(\%)\end{array}$ & $\begin{array}{l}\text { Or } \\
(\%)\end{array}$ \\
\hline \multicolumn{12}{|l|}{ Hole 794B } \\
\hline 1. & $21 \mathrm{R}-5,119$ & 2.77 & 1.26 & 0.01 & 0.21 & 0.66 & 0.04 & 4.95 & 23 & 72 & 4 \\
\hline 2. & $21 R-5,119$ & 2.76 & 1.27 & 0.01 & 0.21 & 0.69 & 0.04 & 4.97 & 22 & 73 & 4 \\
\hline 3. & $21 \mathrm{R}-5,119$ & 2.75 & 1.26 & 0.01 & 0.23 & 0.68 & 0.04 & 4.97 & 24 & 72 & 4 \\
\hline 4. & $21 \mathrm{R}-5,119$ & 2.76 & 1.27 & 0.01 & 0.21 & 0.69 & 0.04 & 4.97 & 22 & 74 & 4 \\
\hline 5. & $21 \mathrm{R}-5,119$ & 2.77 & 1.25 & 0.01 & 0.22 & 0.67 & 0.04 & 4.96 & 23 & 72 & 5 \\
\hline 6. & $21 \mathrm{R}-5,119$ & 2.75 & 1.28 & 0.01 & 0.22 & 0.67 & 0.04 & 4.97 & 24 & 72 & 5 \\
\hline 7. & $21 \mathrm{R}-5,119$ & 2.76 & 1.26 & 0.01 & 0.21 & 0.68 & 0.04 & 4.96 & 23 & 73 & 4 \\
\hline 8. & $21 \mathrm{R}-6,16$ & 2.83 & 1.17 & 0.01 & 0.17 & 0.75 & 0.04 & 4.98 & 18 & 78 & 5 \\
\hline 9. & $21 \mathrm{R}-6,16$ & 2.85 & 1.15 & 0.01 & 0.16 & 0.77 & 0.05 & 4.98 & 16 & 79 & 5 \\
\hline 10. & $21 \mathrm{R}-6,16$ & 2.79 & 1.20 & 0.01 & 0.21 & 0.74 & 0.04 & 4.99 & 21 & 75 & 4 \\
\hline 11. & $21 \mathrm{R}-6,16$ & 2.83 & 1.16 & 0.01 & 0.16 & 0.77 & 0.04 & 4.98 & 17 & 79 & 5 \\
\hline 12. & $21 \mathrm{R}-6,16$ & 2.82 & 1.17 & 0.01 & 0.16 & 0.78 & 0.05 & 4.99 & 16 & 79 & 5 \\
\hline 13. & $21 \mathrm{R}-6,16$ & 2.85 & 1.15 & 0.01 & 0.15 & 0.78 & 0.05 & 4.99 & 16 & 79 & 5 \\
\hline 14. & $21 \mathrm{R}-6,16$ & 2.80 & 1.20 & 0.01 & 0.19 & 0.74 & 0.06 & 4.99 & 19 & 75 & 6 \\
\hline 15. & $21 \mathrm{R}-6,16$ & 2.84 & 1.16 & 0.01 & 0.16 & 0.78 & 0.05 & 4.99 & 16 & 79 & 5 \\
\hline 16. & $21 \mathrm{R}-6,16$ & 2.83 & 1.16 & 0.01 & 0.16 & 0.78 & 0.05 & 4.99 & 16 & 79 & 5 \\
\hline 17. & $21 \mathrm{R}-6,16$ & 2.75 & 1.24 & 0.01 & 0.25 & 0.71 & 0.03 & 5.00 & 25 & 72 & 3 \\
\hline 18. & 2 IR-6, 16 & 2.82 & 1.17 & 0.01 & 0.17 & 0.78 & 0.04 & 5.00 & 17 & 79 & 5 \\
\hline 19. & $21 \mathrm{R}-6,134$ & 2.85 & 1.15 & 0.01 & 0.14 & 0.78 & 0.05 & 4.98 & 15 & 80 & 5 \\
\hline 20. & $21 \mathrm{R}-6,134$ & 2.87 & 1.13 & 0.01 & 0.13 & 0.80 & 0.06 & 4.99 & 13 & 81 & 6 \\
\hline 21. & $21 \mathrm{R}-6,134$ & 2.85 & 1.14 & 0.01 & 0.16 & 0.77 & 0.05 & 4.98 & 16 & 79 & 5 \\
\hline 22. & $21 \mathrm{R}-6,134$ & 2.84 & 1.16 & 0.01 & 0.16 & 0.78 & 0.04 & 4.98 & 16 & 80 & 4 \\
\hline 23. & $21 \mathrm{R}-6,134$ & 2.85 & 1.15 & 0.01 & 0.16 & 0.77 & 0.05 & 4.98 & 16 & 79 & 5 \\
\hline 24. & $21 \mathrm{R}-6,134$ & 2.87 & 1.12 & 0.01 & 0.14 & 0.79 & 0.05 & 4.98 & 15 & 80 & 5 \\
\hline 25. & $21 \mathrm{R}-6,134$ & 2.82 & 1.18 & 0.01 & 0.18 & 0.77 & 0.04 & 4.99 & 18 & 78 & 4 \\
\hline 26. & $21 \mathrm{R}-6,13$ & 2.85 & 1.14 & 0.01 & 0.16 & 0.77 & 0.05 & 4.98 & 16 & 79 & 5 \\
\hline 27. & $21 \mathrm{R}-7,50$ & 2.85 & 1.14 & 0.01 & 0.14 & 0.79 & 0.05 & 4.99 & 15 & 80 & 5 \\
\hline 28. & $21 \mathrm{R}-7,50$ & 2.84 & 1.15 & 0.01 & 0.15 & 0.79 & 0.05 & 4.99 & 15 & 80 & 5 \\
\hline 29. & $21 \mathrm{R}-7,50$ & 2.84 & 1.16 & 0.01 & 0.16 & 0.78 & 0.05 & 4.99 & 16 & 79 & 5 \\
\hline 30. & $21 \mathrm{R}-7,50$ & 2.84 & 1.15 & 0.01 & 0.16 & 0.78 & 0.05 & 4.99 & 16 & 79 & 5 \\
\hline 31. & $21 \mathrm{R}-7,50$ & 2.85 & 1.14 & 0.01 & 0.15 & 0.79 & 0.05 & 4.99 & 15 & 80 & 5 \\
\hline 32. & $21 \mathrm{R}-7.50$ & 2.84 & 1.15 & 0.01 & 0.16 & 0.78 & 0.05 & 4.99 & 16 & 79 & 5 \\
\hline 33. & 2 IR- 7,50 & 2.81 & 1.18 & 0.01 & 0.18 & 0.77 & 0.04 & 5.00 & 18 & 77 & 4 \\
\hline 34. & $21 \mathrm{R}-7,50$ & 2.82 & 1.17 & 0.01 & 0.17 & 0.78 & 0.04 & 5.00 & 17 & 79 & 4 \\
\hline 35. & $21 \mathrm{R}-7,50$ & 2.84 & 1.17 & 0.01 & 0.18 & 0.73 & 0.04 & 4.96 & 19 & 77 & 4 \\
\hline 36. & $21 \mathrm{R}-7,50$ & 2.84 & 1.15 & 0.01 & 0.16 & 0.78 & 0.05 & 4.99 & 16 & 79 & 5 \\
\hline 37. & $21 \mathrm{R}-7,50$ & 2.85 & 1.15 & 0.01 & 0.14 & 0.78 & 0.05 & 4.98 & 15 & 80 & 5 \\
\hline 38. & $21 R-7,50$ & 2.82 & 1.18 & 0.01 & 0.19 & 0.75 & 0.04 & 4.99 & 19 & 77 & 4 \\
\hline 39. & 2IR-CC, 1 & 2.81 & 1.20 & 0.01 & 0.17 & 0.74 & 0.05 & 4.99 & 18 & 77 & 6 \\
\hline 40. & 2IR-CC, 1 & 2.80 & 1.21 & 0.01 & 0.17 & 0.76 & 0.05 & 5.00 & 17 & 78 & 5 \\
\hline 41. & 2IR-CC, 1 & 2.79 & 1.23 & 0.01 & 0.18 & 0.71 & 0.05 & 4.97 & 19 & 76 & 5 \\
\hline 42. & 21R-CC, 1 & 2.80 & 1.21 & 0.01 & 0.18 & 0.72 & 0.05 & 4.97 & 19 & 76 & 5 \\
\hline 43. & 2IR-CC, 1 & 2.80 & 1.21 & 0.01 & 0.16 & 0.76 & 0.05 & 5.00 & 17 & 78 & 5 \\
\hline 44. & 21R-CC, I & 2.81 & 1.20 & 0.01 & 0.16 & 0.77 & 0.05 & 5.00 & 16 & 78 & 5 \\
\hline 45. & 21R-CC, 1 & 2.76 & 1.25 & 0.01 & 0.20 & 0.73 & 0.05 & 4.99 & 21 & 75 & 5 \\
\hline 46. & 21R-CC, 1 & 2.78 & 1.23 & 0.01 & 0.18 & 0.75 & 0.05 & 5.00 & 19 & 76 & 5 \\
\hline 47. & 21R-CC, 1 & 2.82 & 1.20 & 0.01 & 0.15 & 0.75 & 0.05 & 4.98 & 16 & 79 & 6 \\
\hline 48. & $22 \mathrm{R}-1,69$ & 2.85 & 1.15 & 0.01 & 0.16 & 0.78 & 0.05 & 4.98 & 16 & 79 & 5 \\
\hline 49. & $22 \mathrm{R}-1,69$ & 2.83 & 1.17 & 0.01 & 0.17 & 0.77 & 0.04 & 4.99 & 17 & 79 & 4 \\
\hline 50. & $22 \mathrm{R}-1,69$ & 2.81 & 1.19 & 0.01 & 0.20 & 0.75 & 0.04 & 4.99 & 20 & 76 & 4 \\
\hline 51. & $22 \mathrm{R}-1,69$ & 2.81 & 1.19 & 0.01 & 0.18 & 0.76 & 0.04 & 4.99 & 18 & 77 & 4 \\
\hline 52. & $22 \mathrm{R}-1,69$ & 2.84 & 1.15 & 0.01 & 0.18 & 0.77 & 0.04 & 4.99 & 18 & 78 & 4 \\
\hline 53. & $22 \mathrm{R}-1,69$ & 2.85 & 1.14 & 0.01 & 0.15 & 0.79 & 0.05 & 4.99 & 15 & 80 & 5 \\
\hline 54. & $22 \mathrm{R}-1,69$ & 2.83 & 1.16 & 0.01 & 0.16 & 0.79 & 0.05 & 5.00 & 16 & 79 & 5 \\
\hline 55. & $22 \mathrm{R}-1,69$ & 2.84 & 1.15 & 0.01 & 0.17 & 0.77 & 0.05 & 4.99 & 17 & 78 & 5 \\
\hline 56. & $22 \mathrm{R}-1,69$ & 2.85 & 1.14 & 0.01 & 0.15 & 0.79 & 0.05 & 4.99 & 15 & 80 & 5 \\
\hline
\end{tabular}

Hole 796B

\begin{tabular}{|c|c|c|c|c|c|c|c|c|c|c|}
\hline 57. & $11 \mathrm{R}-1,27$ & 2.37 & 1.62 & 0.02 & 0.63 & 0.36 & 0.01 & 5.00 & 63 & 36 \\
\hline 58. & $11 \mathrm{R}-1,27$ & 2.09 & 1.90 & 0.02 & 0.89 & 0.10 & 0.01 & 5.01 & 89 & 10 \\
\hline 59. & $11 \mathrm{R}-1,27$ & 2.09 & 1.91 & 0.02 & 0.90 & 0.09 & 0.00 & 5.01 & 90 & 9 \\
\hline 60. & $11 \mathrm{R}-1,27$ & 2.15 & 1.84 & 0.02 & 0.84 & 0.16 & 0.00 & 5.01 & 84 & 16 \\
\hline 61. & $11 \mathrm{R}-1,27$ & 2.37 & 1.62 & 0.03 & 0.63 & 0.36 & 0.01 & 5.00 & 64 & 36 \\
\hline 62. & $11 \mathrm{R}-1,27$ & 2.54 & 1.46 & 0.01 & 0.45 & 0.53 & 0.01 & 5.00 & 45 & 54 \\
\hline 63. & $11 \mathrm{R}-1,27$ & 2.17 & 1.81 & 0.02 & 0.82 & 0.18 & 0.00 & 5.01 & 82 & 18 \\
\hline 64. & $11 \mathrm{R}-1,61$ & 2.55 & 1,45 & 0.01 & 0.44 & 0.53 & 0.02 & 5.00 & 45 & 54 \\
\hline 65. & $11 \mathrm{R}-1,61$ & 2.58 & 1.41 & 0.01 & 0.42 & 0.56 & 0.02 & 5.00 & 42 & 56 \\
\hline 66. & $11 \mathrm{R}-1,61$ & 2.18 & 1.81 & 0.02 & 0.81 & 0.18 & 0.01 & 5.00 & 81 & 18 \\
\hline 67. & $11 \mathrm{R}-1,61$ & 2.64 & 1.35 & 0.01 & 0.33 & 0.64 & 0.04 & 5.02 & 32 & 63 \\
\hline
\end{tabular}


Table 1 (continued).

\begin{tabular}{|c|c|c|c|c|c|c|c|c|c|c|c|}
\hline $\begin{array}{c}\text { Analysis } \\
\text { no. }\end{array}$ & $\begin{array}{l}\text { Hole, section, } \\
\text { interval }(\mathrm{cm})\end{array}$ & $\mathrm{Si}$ & $\mathrm{Al}$ & $\mathrm{Fe}$ & $\mathrm{Ca}$ & $\mathrm{Na}$ & K & Total & $\begin{array}{l}\text { An } \\
(\%)\end{array}$ & $\begin{array}{l}\mathrm{Ab} \\
(\%)\end{array}$ & $\begin{array}{l}\mathrm{Or} \\
(\%)\end{array}$ \\
\hline 68. & $11 \mathrm{R}-1,61$ & 2.16 & 1.82 & 0.03 & 0.84 & 0.15 & 0.00 & 5.00 & 85 & 15 & 0 \\
\hline 69. & $12 \mathrm{R}-3,1$ & 2.57 & 1.43 & 0.01 & 0.42 & 0.55 & 0.02 & 5.00 & 43 & 55 & 2 \\
\hline 70. & $12 \mathrm{R}-3,1$ & 2.37 & 1.62 & 0.02 & 0.61 & 0.37 & 0.01 & 5.01 & 61 & 37 & $i$ \\
\hline 71. & $12 \mathrm{R}-3,1$ & 2.43 & 1.56 & 0.02 & 0.57 & 0.40 & 0.02 & 5.00 & 57 & 40 & 2 \\
\hline 72. & $12 \mathrm{R}-3,1$ & 2.56 & 1.45 & 0.02 & 0.43 & 0.51 & 0.03 & 4.99 & 44 & 53 & 3 \\
\hline 73. & $12 \mathrm{R}-3,1$ & 2.65 & 1.36 & 0.01 & 0.34 & 0.59 & 0.01 & 4.97 & 36 & 63 & 1 \\
\hline 74. & $16 \mathrm{R}-1,10$ & 2.55 & 1.46 & 0.01 & 0.44 & 0.48 & 0.03 & 4.97 & 46 & 51 & 3 \\
\hline 75. & $16 \mathrm{R}-1,10$ & 2.59 & 1.42 & 0.01 & 0.40 & 0.53 & 0.04 & 4.99 & 41 & 55 & 4 \\
\hline 76. & $16 \mathrm{R}-1,10$ & 2.57 & 1.44 & 0.01 & 0.41 & 0.53 & 0.03 & 4.98 & 42 & 55 & 3 \\
\hline 77. & $16 \mathrm{R}-1,10$ & 2.55 & 1.46 & 0.01 & 0.43 & 0.50 & 0.03 & 4.98 & 45 & 52 & 3 \\
\hline 78. & $16 \mathrm{R}-1,10$ & 2.50 & 1.50 & 0.02 & 0.47 & 0.48 & 0.03 & 5.00 & 48 & 49 & 3 \\
\hline 79. & $16 \mathrm{R}-1,10$ & 2.54 & 1.46 & 0.01 & 0.44 & 0.50 & 0.03 & 4.98 & 45 & 51 & 3 \\
\hline 80. & $16 \mathrm{R}-1,10$ & 2.45 & 1.56 & 0.01 & 0.53 & 0.42 & 0.02 & 4.99 & 55 & 43 & 2 \\
\hline 81. & $16 \mathrm{R}-1,10$ & 2.49 & 1.52 & 0.02 & 0.49 & 0.46 & 0.02 & 4.99 & 50 & 47 & 2 \\
\hline 82. & $16 \mathrm{R}-1,10$ & 2.43 & 1.57 & 0.02 & 0.55 & 0.40 & 0.02 & 4.99 & 56 & 42 & 2 \\
\hline 83. & 17R-1, 30 & 2.61 & 1.39 & 0.02 & 0.37 & 0.59 & 0.03 & 5.00 & 38 & 60 & 3 \\
\hline 84. & $17 \mathrm{R}-1,30$ & 2.49 & 1.50 & 0.02 & 0.51 & 0.46 & 0.01 & 4.99 & 52 & 46 & 1 \\
\hline 85. & $17 \mathrm{R}-1,30$ & 2.52 & 1.48 & 0.02 & 0.46 & 0.48 & 0.02 & 4.99 & 48 & 50 & 2 \\
\hline 86. & $17 \mathrm{R}-1,30$ & 2.45 & 1.55 & 0.02 & 0.55 & 0.41 & 0.02 & 4.99 & 56 & 42 & 2 \\
\hline 87. & $17 \mathrm{R}-1,30$ & 2.58 & 1.43 & 0.01 & 0.41 & 0.52 & 0.03 & 4.98 & 43 & 55 & 3 \\
\hline 88. & $17 \mathrm{R}-1,30$ & 2.55 & 1.45 & 0.02 & 0.44 & 0.50 & 0.02 & 4.98 & 46 & 52 & 2 \\
\hline 89. & $17 \mathrm{R}-1,58$ & 2.70 & 1.31 & 0.01 & 0.28 & 0.67 & 0.04 & 5.00 & 28 & 68 & 4 \\
\hline 90. & $17 \mathrm{R}-1,58$ & 2.38 & 1.61 & 0.02 & 0.62 & 0.34 & 0.02 & 4.99 & 64 & 34 & 2 \\
\hline 91. & $17 \mathrm{R}-1.58$ & 2.42 & 1.57 & 0.02 & 0.62 & 0.33 & 0.00 & 4.96 & 65 & 35 & 0 \\
\hline 92. & $17 \mathrm{R}-1,58$ & 2.58 & 1.43 & 0.01 & 0.40 & 0.52 & 0.03 & 4.98 & 42 & 55 & 3 \\
\hline 93. & $17 \mathrm{R}-1,58$ & 2.35 & 1.65 & 0.03 & 0.64 & 0.32 & 0.01 & 4.99 & 66 & 33 & 1 \\
\hline 94. & $17 \mathrm{R}-1.58$ & 2.53 & 1.48 & 0.01 & 0.45 & 0.49 & 0.02 & 4.98 & 47 & 51 & 2 \\
\hline 95. & $17 \mathrm{R}-1,58$ & 2.64 & 1.37 & 0.01 & 0.34 & 0.58 & 0.03 & 4.98 & 36 & 61 & 4 \\
\hline 96. & $17 \mathrm{R}-1,58$ & 2.70 & 1.31 & 0.01 & 0.27 & 0.64 & 0.05 & 4.98 & 28 & 67 & 5 \\
\hline 97. & $18 \mathrm{R}-1,21$ & 2.30 & 1.70 & 0.02 & 0.66 & 0.30 & 0.01 & 5.00 & 68 & 31 & 1 \\
\hline 98. & $18 \mathrm{R}-1,21$ & 2.56 & 1.45 & 0.01 & 0.41 & 0.52 & 0.02 & 4.98 & 43 & 54 & 3 \\
\hline 99. & $18 \mathrm{R}-1,21$ & 2.29 & 1.70 & 0.03 & 0.70 & 0.29 & 0.01 & 5.01 & 70 & 29 & 1 \\
\hline 100. & $18 \mathrm{R}-1,21$ & 2.71 & 1.30 & 0.01 & 0.28 & 0.63 & 0.04 & 4.97 & 29 & 66 & 4 \\
\hline 101. & $18 \mathrm{R}-1,21$ & 2.71 & 1.30 & 0.01 & 0.28 & 0.65 & 0.03 & 4.98 & 29 & 68 & 3 \\
\hline 102. & $18 \mathrm{R}-1,21$ & 2.55 & 1.46 & 0.01 & 0.44 & 0.48 & 0.02 & 4.97 & 46 & 51 & 3 \\
\hline 103. & $18 \mathrm{R}-1,21$ & 2.55 & 1.46 & 0.01 & 0.43 & 0.49 & 0.02 & 4.97 & 46 & 52 & 3 \\
\hline 104. & $18 \mathrm{R}-1,21$ & 2.43 & 1.57 & 0.02 & 0.55 & 0.41 & 0.01 & 4.99 & 57 & 42 & 1 \\
\hline 105. & $18 \mathrm{R}-3,138$ & 2.62 & 1.39 & 0.01 & 0.36 & 0.56 & 0.03 & 4.98 & 37 & 59 & 3 \\
\hline 106. & $18 \mathrm{R}-3,138$ & 2.64 & 1.37 & 0.01 & 0.34 & 0.58 & 0.03 & 4.98 & 36 & 61 & 3 \\
\hline 107. & $18 \mathrm{R}-3,138$ & 2.75 & 1.27 & 0.01 & 0.23 & 0.69 & 0.04 & 4.98 & 24 & 72 & 4 \\
\hline 108. & $18 \mathrm{R}-3.138$ & 2.67 & 1.34 & 0.01 & 0.33 & 0.58 & 0.04 & 4.97 & 35 & 61 & 4 \\
\hline 109. & $18 \mathrm{R}-3,138$ & 2.71 & 1.30 & 0.01 & 0.29 & 0.63 & 0.04 & 4.98 & 30 & 66 & 4 \\
\hline 110. & $18 \mathrm{R}-3,138$ & 2.70 & 1.31 & 0.01 & 0.29 & 0.62 & 0.04 & 4.97 & 30 & 65 & 4 \\
\hline 111. & $18 \mathrm{R}-3,138$ & 2.66 & 1.34 & 0.01 & 0.32 & 0.61 & 0.04 & 4.99 & 33 & 63 & 4 \\
\hline 112. & $18 \mathrm{R}-4,38$ & 2.46 & 1.53 & 0.02 & 0.54 & 0.43 & 0.01 & 4.99 & 55 & 43 & 1 \\
\hline 113. & $18 \mathrm{R}-4,38$ & 2.76 & 1.24 & 0.01 & 0.25 & 0.69 & 0.05 & 4.99 & 25 & 70 & 5 \\
\hline 114. & $18 \mathrm{R}-4,38$ & 2.77 & 1.22 & 0.01 & 0.24 & 0.70 & 0.05 & 4.98 & 25 & 71 & 5 \\
\hline 115. & $18 \mathrm{R}-4,38$ & 2.73 & 1.27 & 0.01 & 0.28 & 0.66 & 0.04 & 4.98 & 29 & 67 & 4 \\
\hline 116. & $18 R-4,38$ & 2.69 & 1.30 & 0.01 & 0.32 & 0.63 & 0.04 & 4.98 & 32 & 64 & 4 \\
\hline 117. & $18 \mathrm{R}-4,38$ & 2.79 & 1.21 & 0.01 & 0.22 & 0.71 & 0.05 & 4.98 & 23 & 72 & 5 \\
\hline 118. & $18 \mathrm{R}-4,38$ & 2.69 & 1.30 & 0.01 & 0.31 & 0.64 & 0.04 & 4.99 & 31 & 65 & 4 \\
\hline 119. & $18 R-4,38$ & 2.29 & 1.69 & 0.01 & 0.71 & 0.28 & 0.01 & 5.00 & 71 & 28 & 1 \\
\hline 120. & $18 R-4,38$ & 2.73 & 1.26 & 0.01 & 0.28 & 0.65 & 0.04 & 4.98 & 29 & 67 & 4 \\
\hline 121. & $18 \mathrm{R}-4,38$ & 2.49 & 1.50 & 0.01 & 0.50 & 0.47 & 0.02 & 4.99 & 51 & 47 & 2 \\
\hline 122. & $18 R-4,38$ & 2.75 & 1.24 & 0.01 & 0.27 & 0.67 & 0.05 & 4.98 & 27 & 68 & 5 \\
\hline 123. & $18 R-4,38$ & 2.53 & 1.45 & 0.01 & 0.47 & 0.52 & 0.02 & 5.00 & 47 & 51 & 2 \\
\hline 124. & $18 \mathrm{R}-4,90$ & 2.73 & 1.26 & 0.01 & 0.28 & 0.66 & 0.04 & 4.99 & 28 & 67 & 4 \\
\hline 125. & $18 \mathrm{R}-4,90$ & 2.71 & 1.29 & 0.01 & 0.30 & 0.64 & 0.04 & 4.98 & 30 & 66 & 4 \\
\hline 126. & $18 \mathrm{R}-4,90$ & 2.75 & 1.24 & 0.01 & 0.26 & 0.68 & 0.05 & 4.99 & 26 & 69 & 5 \\
\hline 127. & $18 \mathrm{R}-4,90$ & 2.54 & 1.45 & 0.01 & 0.45 & 0.52 & 0.02 & 5.00 & 45 & 53 & 2 \\
\hline 128. & $18 \mathrm{R}-4,90$ & 2.68 & 1.31 & 0.01 & 0.32 & 0.63 & 0.03 & 4.99 & 33 & 64 & 3 \\
\hline 129. & $18 R-4,90$ & 2.66 & 1.33 & 0.01 & 0.34 & 0.61 & 0.03 & 4.98 & 35 & 62 & 3 \\
\hline 130. & $18 \mathrm{R}-4,90$ & 2.70 & 1.29 & 0.01 & 0.31 & 0.63 & 0.03 & 4.98 & 32 & 65 & 4 \\
\hline 131. & $18 \mathrm{R}-4,90$ & 2.72 & 1.27 & 0.01 & 0.30 & 0.65 & 0.04 & 4.98 & 30 & 66 & 4 \\
\hline 132. & $18 \mathrm{R}-4,90$ & 2.74 & 1.26 & 0.01 & 0.26 & 0.68 & 0.04 & 4.99 & 27 & 69 & 4 \\
\hline 133. & $18 R-4,90$ & 2.77 & 1.23 & 0.01 & 0.24 & 0.68 & 0.04 & 4.98 & 25 & 70 & 4 \\
\hline 134. & $18 \mathrm{R}-4,90$ & 2.77 & 1.23 & 0.01 & 0.25 & 0.66 & 0.04 & 4.97 & 26 & 69 & 5 \\
\hline 135. & $18 \mathrm{R}-4,90$ & 2.64 & 1.36 & 0.01 & 0.36 & 0.60 & 0.02 & 4.99 & 36 & 61 & 3 \\
\hline 136. & $18 \mathrm{R}-4,116$ & 2.67 & 1.34 & 0.01 & 0.33 & 0.58 & 0.04 & 4.96 & 35 & 62 & 4 \\
\hline 137. & $18 \mathrm{R}-4,116$ & 2.71 & 1.31 & 0.01 & 0.29 & 0.59 & 0.04 & 4.95 & 32 & 64 & 4 \\
\hline 138. & $18 \mathrm{R}-4,116$ & 2.68 & 1.33 & 0.01 & 0.31 & 0.60 & 0.04 & 4.97 & 33 & 63 & 4 \\
\hline 139. & $18 \mathrm{R}-4,116$ & 2.74 & 1.27 & 0.01 & 0.26 & 0.65 & 0.05 & 4.98 & 27 & 68 & 5 \\
\hline 140. & $18 \mathrm{R}-4,116$ & 2.67 & 1.33 & 0.01 & 0.33 & 0.61 & 0.04 & 4.98 & 34 & 62 & 4 \\
\hline 141. & $18 \mathrm{R}-4,116$ & 2.70 & 1.32 & 0.01 & 0.31 & 0.57 & 0.04 & 4.95 & 34 & 62 & 4 \\
\hline
\end{tabular}


Table 1 (continued).

\begin{tabular}{|c|c|c|c|c|c|c|c|c|c|c|c|}
\hline $\begin{array}{c}\text { Analysis } \\
\text { no. }\end{array}$ & $\begin{array}{l}\text { Hole, section, } \\
\text { interval }(\mathrm{cm})\end{array}$ & $\mathrm{Si}$ & Al & $\mathrm{Fe}$ & $\mathrm{Ca}$ & $\mathrm{Na}$ & K & Total & $\begin{array}{l}\text { An } \\
(\%)\end{array}$ & $\begin{array}{l}\mathrm{Ab} \\
(\%)\end{array}$ & $\begin{array}{l}\text { Or } \\
(\%)\end{array}$ \\
\hline 142. & $18 \mathrm{R}-4,116$ & 2.71 & 1.29 & 0.01 & 0.30 & 0.63 & 0.04 & 4.98 & 31 & 65 & 4 \\
\hline 143. & $18 \mathrm{R}-4,116$ & 2.72 & 1.29 & 0.01 & 0.28 & 0.62 & 0.04 & 4.97 & 29 & 66 & 5 \\
\hline 144. & $18 \mathrm{R}-4,116$ & 2.71 & 1.31 & 0.01 & 0.29 & 0.60 & 0.04 & 4.96 & 31 & 64 & 5 \\
\hline 145. & $18 \mathrm{R}-4,116$ & 2.75 & 1.26 & 0.01 & 0.25 & 0.67 & 0.05 & 4.99 & 25 & 69 & 5 \\
\hline 146. & $18 \mathrm{R}-4,116$ & 2.68 & 1.33 & 0.01 & 0.30 & 0.60 & 0.04 & 4.97 & 32 & 64 & 4 \\
\hline 147. & $18 \mathrm{R}-4,116$ & 2.71 & 1.30 & 0.01 & 0.28 & 0.63 & 0.05 & 4.98 & 29 & 66 & 5 \\
\hline 148. & $18 \mathrm{R}-4,116$ & 2.75 & 1.26 & 0.01 & 0.24 & 0.67 & 0.05 & 4.98 & 25 & 70 & 5 \\
\hline 149. & $18 \mathrm{R}-4,116$ & 2.23 & 1.78 & 0.01 & 0.72 & 0.26 & 0.01 & 5.01 & 73 & 26 & 1 \\
\hline 150. & $18 \mathrm{R}-4,116$ & 2.68 & 1.33 & 0.01 & 0.31 & 0.60 & 0.04 & 4.97 & 33 & 63 & 4 \\
\hline 151. & $18 \mathrm{R}-4,116$ & 2.69 & 1.33 & 0.01 & 0.30 & 0.60 & 0.04 & 4.97 & 32 & 64 & 4 \\
\hline 152. & $18 \mathrm{R}-4,116$ & 2.71 & 1.31 & 0.01 & 0.29 & 0.62 & 0.04 & 4.97 & 30 & 65 & 4 \\
\hline 153. & $18 \mathrm{R}-4,116$ & 2.69 & 1.32 & 0.01 & 0.30 & 0.62 & 0.04 & 4.98 & 31 & 65 & 4 \\
\hline 154. & $18 \mathrm{R}-4,116$ & 2.69 & 1.33 & 0.01 & 0.29 & 0.60 & 0.04 & 4.96 & 31 & 64 & 4 \\
\hline 155. & $19 \mathrm{R}-1,105$ & 2.17 & 1.82 & 0.03 & 0.82 & 0.17 & 0.01 & 5.01 & 82 & 17 & 1 \\
\hline 156. & $19 \mathrm{R}-1,105$ & 2.13 & 1.85 & 0.03 & 0.86 & 0.14 & 0.00 & 5.01 & 86 & 14 & 0 \\
\hline 157. & $19 \mathrm{R}-1,105$ & 2.24 & 1.74 & 0.03 & 0.76 & 0.22 & 0.01 & 5.00 & 76 & 23 & 1 \\
\hline 158. & $19 \mathrm{R}-1,105$ & 2.22 & 1.77 & 0.03 & 0.77 & 0.21 & 0.01 & 5.00 & 78 & 21 & 1 \\
\hline 159. & $19 \mathrm{R}-1,105$ & 2.21 & 1.79 & 0.03 & 0.76 & 0.20 & 0.01 & 4.99 & 78 & 21 & 1 \\
\hline 160. & $19 \mathrm{R}-1,105$ & 2.19 & 1.80 & 0.02 & 0.79 & 0.19 & 0.01 & 5.00 & 80 & 19 & 1 \\
\hline 161. & $22 \mathrm{R}-1,118$ & 2.24 & 1.75 & 0.03 & 0.74 & 0.23 & 0.01 & 5.00 & 76 & 24 & 1 \\
\hline 162. & $22 \mathrm{R}-1,118$ & 2.24 & 1.75 & 0.03 & 0.74 & 0.23 & 0.01 & 5.00 & 76 & 24 & 1 \\
\hline 163. & $22 \mathrm{R}-1,118$ & 2.47 & 1.53 & 0.02 & 0.52 & 0.46 & 0.02 & 5.01 & 52 & 46 & 2 \\
\hline 164. & $22 \mathrm{R}-1,118$ & 2,23 & 1.74 & 0.02 & 0.76 & 0.23 & 0.01 & 5.00 & 76 & 23 & 1 \\
\hline 165. & $22 \mathrm{R}-1,118$ & 2.48 & 1.51 & 0.04 & 0.49 & 0.46 & 0.03 & 5.00 & 50 & 47 & 3 \\
\hline 166. & $22 \mathrm{R}-1,118$ & 2.43 & 1.57 & 0.02 & 0.52 & 0.44 & 0.02 & 5.01 & 53 & 45 & 2 \\
\hline 167. & $22 \mathrm{R}-1,118$ & 2.30 & 1.69 & 0.02 & 0.68 & 0.31 & 0.01 & 5.01 & 68 & 31 & 1 \\
\hline 168. & $22 \mathrm{R}-1,118$ & 2.32 & 1.68 & 0.02 & 0.66 & 0.32 & 0.01 & 5.00 & 67 & 32 & 1 \\
\hline 169. & $22 \mathrm{R}-1,118$ & 2.51 & 1.48 & 0.02 & 0.49 & 0.49 & 0.02 & 5.00 & 49 & 50 & 2 \\
\hline 170. & $22 \mathrm{R}-1,118$ & 2.32 & 1.66 & 0.02 & 0.67 & 0.31 & 0.01 & 5.00 & 68 & 31 & 1 \\
\hline 171. & $22 \mathrm{R}-1,118$ & 2.18 & 1.80 & 0.02 & 0.79 & 0.22 & 0.01 & 5.02 & 78 & 21 & 1 \\
\hline 172. & $22 \mathrm{R}-1,118$ & 2.19 & 1.79 & 0.03 & 0.79 & 0.21 & 0.01 & 5.02 & 78 & 21 & 1 \\
\hline 173. & $22 \mathrm{R}-1,118$ & 2.23 & 1.76 & 0.03 & 0.75 & 0.22 & 0.01 & 5.00 & 77 & 23 & 1 \\
\hline 174. & $22 \mathrm{R}-1,118$ & 2.27 & 1.71 & 0.03 & 0.71 & 0.27 & 0.01 & 5.00 & 72 & 27 & 1 \\
\hline
\end{tabular}

Note: The sample numbers are sequential from the top to the bottom of each hole. See text for description of sample acquisition parameters. Elemental data are presented as atomic fractions normalized to eight oxygens. Anorthite $(A n)$, albite $(\mathrm{Ab})$, and orthoclase $(\mathrm{Or})$, mole\% are also presented.

probably at bathyal depths or deeper. Maximum water depth for this eruption is not constrained.

The blue tuff at Site 796 consists of more heterogeneous tuffaceous detritus including abundant bubble wall glass shards formed by probable shallow-marine or subaerial magmatic eruption. Overall facies characteristics suggest that blue tuffs at this location were deposited by a series of density flows generated on an unstable depositional slope. There is no clear evidence to indicate that the magmatic eruption that produced the majority of pyrogenic detritus in blue tuffs was contemporaneous with downslope reworking by density flows. The admixture of accidental fragments (material other than comagmatic pyroclasts), including glauconitic pellets, suggests more protracted reworking prior to redeposition of blue tuffs at Site 796 compared to Site 794 .

\section{Pyrogenic Crystal Chemistry}

Microprobe analysis indicates that the average An mole\% from plagioclase feldspar in blue tuffs from Site 794 is $18 \pm 3$. This homogeneous composition suggests that the plagioclase crystal population is essentially cogenetic. The low An mole \% of these feldspars is in strong contrast to the composition of plagioclase in intrusive rocks recovered from acoustic basement at this site (An mole $\%=$ $45-90)$. It is unlikely that the blue tuff at Site 794 is genetically related to subjacent intrusives.

The average An mole\% of plagioclase from blue tuff samples at Site 796 is $36 \pm 12$. These plagioclases are clearly a mixture of at least two populations. The dominant population with average An\% of $30 \pm 4$ is interpreted as the probable comagmatic plagioclase population, distinct in composition from plagioclase at Site 794. The oligo- clase to andesine composition of these plagioclase is consistent with derivation from andesitic magmas.

\section{${ }^{40} \mathrm{Ar} /{ }^{39} \mathrm{Ar}$ Dating}

The results of ${ }^{40} \mathrm{Ar} /{ }^{39} \mathrm{Ar}$ dating of plagioclase, biotite and hornblende crystals from blue tuffs at Sites 794 and 796 are consistent with the biochronology reported by Tamaki, Pisciotto, Allan, et al. (1990). The ages for multiple crystal analysis in two samples from Site 794 are concordant and average $14.86 \mathrm{Ma}$. This age is consistent with ages based on sediment-accumulation rate extrapolation (Tamaki, Pisciotto, Allan, et al., 1990) and corroborates initial estimates of the minimum age of basement at this site at 16.2 Ma (Tamaki, Pisciotto, Allan, et al., 1990).

The results of multiple crystal analyses, including plagioclase, biotite, and hornblende, from one sample from Site 796 are more complex. Three concordant plagioclase crystal ages constrain the maximum age of blue tuffs at $7.61 \mathrm{Ma}$, generally consistent with interpretations based on biostratigraphy and extrapolations of sediment accumulation rates (Tamaki, Pisciotto, Allan, et al., 1990). Other mineral ages are incompatible with biostratigraphic data and are considered either older, inherited detrital ages or younger ages dating alteration.

The observed age of blue tuffs recovered during Leg 127 drilling in the Japan Sea are comparable to ${ }^{40} \mathrm{Ar} /{ }^{39} \mathrm{Ar}$ ages of trachyandesite to basalt samples dredged from the Yamato Seamount chain and reported by Kaneoka et al, (1990). The composition of plagioclase phenocrysts in these generally alkaline rocks from seamounts is probably comparable to plagioclase from blue tuffs $\left(\mathrm{An}_{10-50}\right)$. Magmatism related to the emplacement of the Yamato Seamount chain may be related to blue tuff magmatism. 
Table 2. Results of ${ }^{40} \mathrm{Ar} /{ }^{39} \mathrm{Ar}$ age dating. ${ }^{\mathrm{a}}$

\begin{tabular}{|c|c|c|c|c|c|c|c|c|}
\hline $\begin{array}{c}\text { Sample } \\
\text { no. }\end{array}$ & Mineral & ${ }^{40} \mathrm{Ar}(\mathrm{nA})$ & ${ }^{37} \mathrm{Ar} /{ }^{39} \mathrm{Ar}$ & $38 \mathrm{Ar} r^{39} \mathrm{Ar}$ & ${ }^{40} \mathrm{Ar} /{ }^{39} \mathrm{Ar}$ & ${ }^{40} \operatorname{Ar}(\%)$ & $\begin{array}{l}\text { Age } \\
(\mathrm{Ma})\end{array}$ & $\pm \sigma$ \\
\hline \multicolumn{9}{|l|}{$794 \mathrm{~B}-21 \mathrm{R}-5,112-115 \mathrm{~cm}$} \\
\hline 4402.01 & Plagioclase & 0.5552 & 4.4718 & 0.0114 & 0.3962 & 78.9 & 16.13 & 0.51 \\
\hline 4402.02 & Plagioclase & 0.2657 & 1.7979 & 0.0105 & 0.3556 & 90.0 & 16.46 & 0.82 \\
\hline 4402.03 & Plagioclase & 0.3320 & 1.8567 & 0.0109 & 0.3600 & 76.6 & 14.21 & 0.68 \\
\hline 4402.04 & Plagioclase & 0.2361 & 3.3081 & 0.0113 & 0.4236 & 64.2 & 14.03 & 1.05 \\
\hline 4402.05 & Plagioclase & 0.4512 & 2.9305 & 0.0118 & 0.7250 & 35.0 & 13.07 & 1.03 \\
\hline 4402.06 & Plagioclase & 0.1873 & 2.3345 & 0.0113 & 0.3337 & 94.7 & 16.29 & 1.01 \\
\hline 4402.07 & Plagioclase & 0.2288 & 1.5829 & 0.0110 & 0.3333 & 80.8 & 13.88 & 0.85 \\
\hline 4402.08 & Plagioclase & 0.3316 & 1.9234 & 0.0113 & 0.3331 & 86.8 & 14.89 & 0.63 \\
\hline Mean \pm SEM & & & & & & & 14.87 & 0.16 \\
\hline \multicolumn{9}{|l|}{ 794B-2IR-1, 69-72 cm } \\
\hline 4404.01 & Plagioclase & 0.3117 & 2.2854 & 0.0107 & 0.4132 & 79.0 & 16.82 & 0.79 \\
\hline 4404.02 & Plagioclase & 0.3622 & 2.2176 & 0.0113 & 0.3309 & 89.0 & 15.17 & 0.53 \\
\hline 4404.03 & Plagioclase & 0.3725 & 2.0747 & 0.0114 & 0.4688 & 52.4 & 12.65 & 0.82 \\
\hline 4404.04 & Plagioclase & 0.2250 & 2.0086 & 0.0117 & 0.3496 & 81.2 & 14.62 & 0.88 \\
\hline 4404.05 & Plagioclase & 0.7950 & 1.6820 & 0.0115 & 0.3356 & 82.1 & 14.19 & 0.27 \\
\hline 4404.06 & Plagioclase & 0.4248 & 2.6924 & 0.0114 & 0.3507 & 86.7 & 15.66 & 0.52 \\
\hline 4404.07 & Plagioclase & 0.3925 & 2.9322 & 0.0114 & 0.3615 & 79.8 & 14.87 & 0.55 \\
\hline Mean \pm SEM & & & & & & & 14.85 & 0.18 \\
\hline \multicolumn{9}{|l|}{ 796B-18R-4, 90-93 } \\
\hline $\mathrm{b}_{4403.01}$ & Plagioclase & 1.0345 & 3.2813 & 0.0123 & 1.0411 & 16.2 & 8.71 & 0.53 \\
\hline$c_{4403.02}$ & Plagioclase & 0.7412 & 2.9057 & 0.0122 & 0.5679 & 16.8 & 4.94 & 0.57 \\
\hline b 4403.03 & Plagioclase & 0.2581 & 3.2918 & 0.0122 & 0.4721 & 29.1 & 7.11 & 0.72 \\
\hline b 4403.04 & Plagioclase & 2.9462 & 3.1826 & 0.0125 & 1.5966 & 8.5 & 7.00 & 0.61 \\
\hline$c_{4403.05}$ & Biotite & 1.7958 & 0.0422 & 0.0157 & 0.6863 & 14.6 & 5.15 & 0.28 \\
\hline${ }^{c} 4403.06$ & Biotite & 0.5540 & 0.0146 & 0.0157 & 0.1406 & 69.9 & 5.07 & 0.08 \\
\hline 4403.07 & Hornblende & 0.6504 & 9.3093 & 0.0427 & 0.2835 & 66.6 & 9.79 & 0.50 \\
\hline Mean \pm SEM ( ${ }^{b}$ samples) & & & & & & & 7.61 & 0.56 \\
\hline Mean \pm SEM ( ${ }^{c}$ samples) & & & & & & & 5.05 & 0.31 \\
\hline \multicolumn{9}{|c|}{$\begin{array}{l}\text { Ar isotopic data are derived from total laser fusion. Plagioclase grains from Site } 794 \mathrm{~B} \text { were degassed at } 0.3 \mathrm{~W} \text { laser power output } \\
\text { before fusion to help remove atmospheric } \mathrm{Ar} \text { contamination. These data are corrected for mass discrimination, radioactive decay } \\
\text { nucleogenic interferences, procedural blanks, and atmospheric contamination. }{ }^{37} \mathrm{Ar},{ }^{38} \mathrm{Ar} \text {, and }{ }^{39} \mathrm{Ar} \text { as used to refer to the proportion } \\
\text { of these isotopes derived by neutron activation of } \mathrm{Ca}, \mathrm{Cl} \text {, and } \mathrm{K} \text {, respectively. Reported errors reflect uncertainties accrued from } \\
\text { all corrections plus regression of isotopic data. Errors in the apparent ages do not reflect uncertainty in the age of the standard. } \\
\mathrm{SEM}=\text { standard error of the mean. }\end{array}$} \\
\hline Mean \pm SEM. & & & & & & & & \\
\hline
\end{tabular}

Table 3. Results of ${ }^{87} \mathrm{Sr} /{ }^{86} \mathrm{Sr}$ isotopic composition analysis. See text for description of acquisition parameters.

\begin{tabular}{lcc}
\hline \multicolumn{1}{c}{ Sample } & $\begin{array}{c}\text { An } \\
(\%)\end{array}$ & ${ }^{87} \mathrm{Sr} /{ }^{86} \mathrm{Sr}$ \\
\hline $794 \mathrm{~B}-21 \mathrm{R}-6,16-19 \mathrm{~cm}$ & $15.7-25.2$ & $0.704512 \pm 13$ \\
$794 \mathrm{~B}-21 \mathrm{R}-6,69-72 \mathrm{~cm}$ & $14.9-20.3$ & $0.704390 \pm 23$ \\
$794 \mathrm{~B}-23 \mathrm{R}-\mathrm{CC}, 10-13 \mathrm{~cm}$ & $\mathrm{NA}$ & $0.709547 \pm 13$ \\
$796 \mathrm{~B}-18 \mathrm{R}-4,90-93 \mathrm{~cm}$ & $25.2-45.5$ & $0.704464 \pm 20$ \\
$796 \mathrm{~B}-18 \mathrm{R}-4,131-134 \mathrm{~cm}$ & $\mathrm{NA}$ & $0.704199 \pm 20$ \\
Standard NBS-987 & NA & $0.710200 \pm 13$ \\
\hline
\end{tabular}

Note: Errors are 2 sigma uncertainties in observed run. No accuracy is better than \pm 2 from experience with replicate runs. $\mathrm{NA}=$ not analyzed.

\section{${ }^{87} \mathrm{Sr} /{ }^{86} \mathrm{Sr}$ Isotopic Composition}

Limited data on the ${ }^{87} \mathrm{Sr} /{ }^{86} \mathrm{Sr}$ isotopic composition of plagioclase crystal separates from blue tuff samples indicates consistent ratios ranging from 0.7045 to 0.7042 . One anomalous value of 0.7095 is discounted as attributable to probable contamination by clay alteration products. These data suggest an origin for blue tuffs at both Sites 794 and 796 from mantle-generated magmas in an island arc setting. Strontium isotope ratios are inconsistent with the derivation of magmas from more primitive mantle sources analogous to oceanic spreading centers.
The isotope geochemistry of basement rocks in the Yamato basin (Cousens and Allen, this volume) indicates virtually indistinguishable strontium isotopic signature for Japan arc rocks compared to Japan Sea basement. The range of isotopic composition of these suites of igneous rocks also encompasses the isotopic composition of blue tuffs. As such, little can be inferred regarding the petrologic affinity of blue tuffs relative to regional trends in strontium isotope geochemistry of arc and backarc rocks in the Japan Sea region. The strontium isotope geochemistry of Yamato Seamount chain volcanic rocks (0.70357-0.70388; Kaneoka et al., 1990) suggests ${ }^{87} \mathrm{Sr} /{ }^{86} \mathrm{Sr}$ isotopic composition significantly lower than that observed for plagioclase grains in blue tuffs. The inferred relationship between Yamato Seamount chain volcanic rocks and blue tuffs, suggested by similar age, composition, and geographic location is not supported by the disparity in strontium isotope chemistry, however.

\section{Correlation of Blue Tuffs in the Yamato and Japan Basins}

On the basis of sedimentologic facies characteristics, plagioclase composition, and age, distinctive, coarse-grained, Miocene blue tuffs recovered at Sites 794 and 796 are not closely related. Sedimentologic characteristics suggest generally similar depositional conditions for the two successions. Both sequences were deposited by gravity flows in probable bathyal or deeper water depths. But the initial magmatism responsible for the formation of tuffaceous debris at Site 794 was probably submarine phreatomagmatic compared with subaerial or shallow submarine magmatic at Site 796. 
The age of blue tuffs at Site 794 is 7 m.y. older than at Site 796 . Although these units were clearly not deposited as a result of contemporaneous magmatism, further differences in plagioclase crystal chemistry and sedimentology indicate that there is no clear genetic relationship between these units. The initial identification and correlation of coarsegrained, blue to blue-gray volcaniclastics (Tamaki, Pisciotto, Allan, et al., 1990) was made on the basis of gross physical appearance and the similarity of associated strata. The gross similarity in physical appearance of the blue tuff is mainly a function of the similarity of alteration products of the dominantly glassy vitroclast-rich strata to blue-colored, clay alteration products. Also, the generally massive to stratified and graded structures in these successions are a function of crudely similar, density flow depositional mechanisms.

Lithostratigraphic correlation of blue tuffs and the implication that such strata are indicative of magmatism associated with backarc spreading in the Japan Sea region are considered invalid by the authors. Rather, Miocene blue to blue-gray bentonitic tuff and tuffaceous sandstones of intermediate composition are a product of a protracted, 6- to 8-m.y., period of subduction-related submarine to subaerial volcanism in the Japan Sea backarc basin.

\section{REFERENCES}

Boles, J. R., 1982. Active albitization of plagioclase, Gulf Coast Tertiary. Am. J. Sci., 282:165-180.

Cass, R.A.F., and Wright, J. V., 1987. Volcanic Successions-Modern and Ancient: London (Allen and Unwin).

Cebula, G. T., Kunk, M., Mehnert, H. H., Naeser, C. W., Obradovich, J. D., and Sutter, J.F., 1986. The Fish Canyon Tuff: a potential standard for the ${ }^{40} \mathrm{Ar}-{ }^{39} \mathrm{Ar}$ and fission-track methods. Terra Cognita, 6:139-140.

Deino, A. L., and Potts, R., 1990. Single-Crystal ${ }^{40} \mathrm{Ar} /{ }^{39} \mathrm{Ar}$ dating of the Olargesaile Formation, Rift. J. Geophys. Res., 95:8453-8470.

Faure, G., 1986. Principles of Isotope Geochemistry (2nd ed.): New York (Wiley).

Fisher, R. V., 1984. Submarine volcaniclastic rocks. In Kokelaar, B. P., and Howells, M. F. (Eds.), Marginal Basin Geology: Volcanic and Associated
Sedimentary and Tectonic Processes in Modern and Ancient Marginal Basins. Geol. Soc. Spec. Publ. London, 16:5-27.

Fisher, R. V., and Schmincke, H.U., 1984. Pyroclastic Rocks: Berlin(Springer Verlag).

Fiske, R. S., 1969. Recognition and significance of pumice in marine pyroclastic rocks. Geol Soc. Am. Bull., 80:1-8.

Fiske, R. S., and Matsuda, T., 1964. Submarine equivalents of ash flows in the Tokiwa Formation, Japan. Am. J. Sci., 262:76-106.

Gill, J., Torssander, P., Lapiere, H., Taylor, R., Kaiho, K., Koyama, M., Kusukabe, M., Aitchison, J., Cisowski, S., Dadey, K., Fujioka, K., Klaus, A., Lovell, M., Marsagila, K., Pezard, P., Taylor, B., and Tazake, K., 1990. Explosive deep water basalt in the Sumisu Backarc Rift. Sci. Rep., 248:1214-1217.

Heiken, G. H., 1972. Morphology and petrology of volcanic ashes. Geol Soc. Am. Bull., 83:1961-1988.

, 1974. An Atlas of Volcanic Ash. Smithsonian Contrib. Earth Sci., 12.

Kaneoka, I., Notsu, K., Takigami, Y., Fujioka, K., and Sakai, H., 1990. Constraints on the evolution of the Japan Sea based on ${ }^{40} \mathrm{Ar} /{ }^{39} \mathrm{Ar}$ ages and $\mathrm{Sr}$ isotopic ratios for volcanic rocks of the Yamato Seamount chain in the Japan Sea. Earth Planet. Sci. Lett., 97:211-225.

Nier, A. O., 1950. A redetermination of the relative abundances of the isotopes of carbon, nitrogen, oxygen, argon, and potassium. Phys. Rev, 77:789-793.

Renne, P. R., Fulford, M. M., and Busby-Spera, C. J., 1991. High resolution ${ }^{40} \mathrm{Ar} /{ }^{39} \mathrm{Ar}$ chronostratigraphy of the Late Cretaceous El Gallo Formation, Baja California del Norte, Mexico. Geophys. Res. Lett., 18:459-462.

Tamaki, K., Pisciotto, K., Allan, J., et al., 1990. Proc. ODP, Init. Repts., 127: College Station, TX (Ocean Drilling Program).

Wohletz, K. H., 1983. Mechanisms of hydrovolcanic pyroclast formation: grain-size, scanning electron microscopy and experimental studies. $J$. Volcanol. Geotherm. Res., 17:31-63.

Date of initial receipt: 22 May 1991

Date of acceptance: 20 January 1992

Ms 127/128B-185 
1

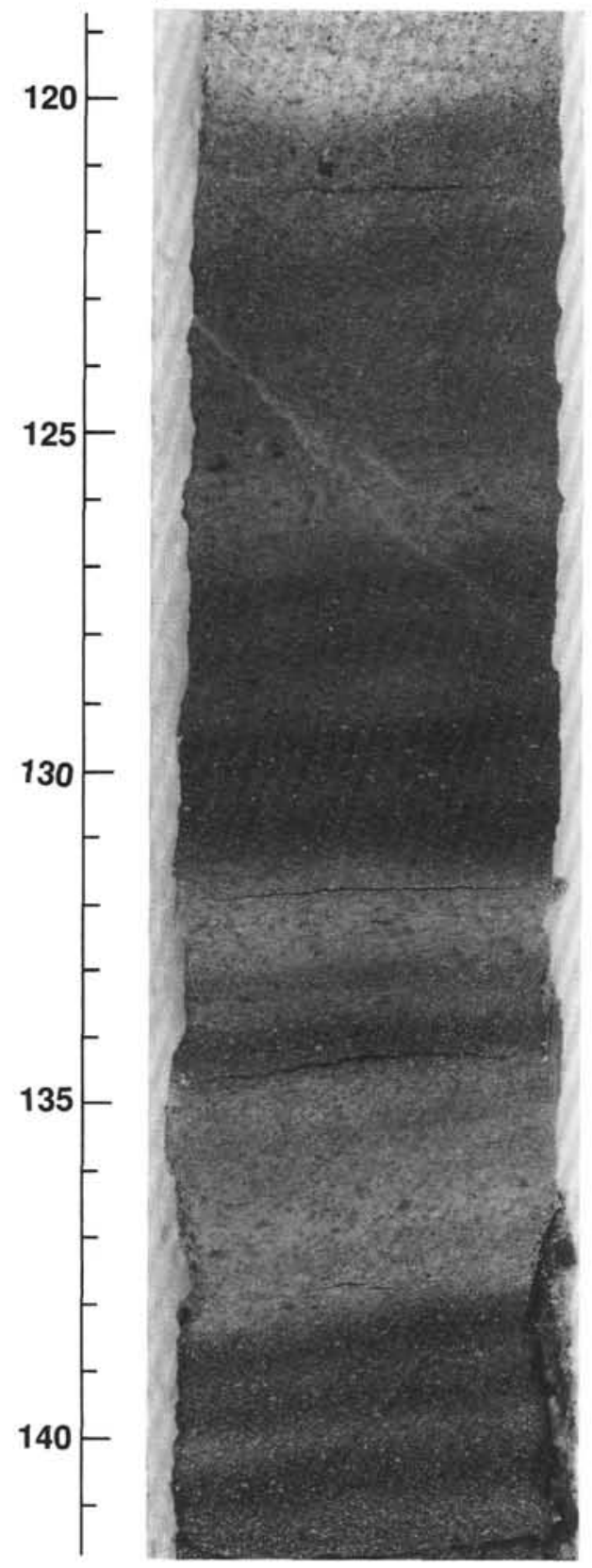

2

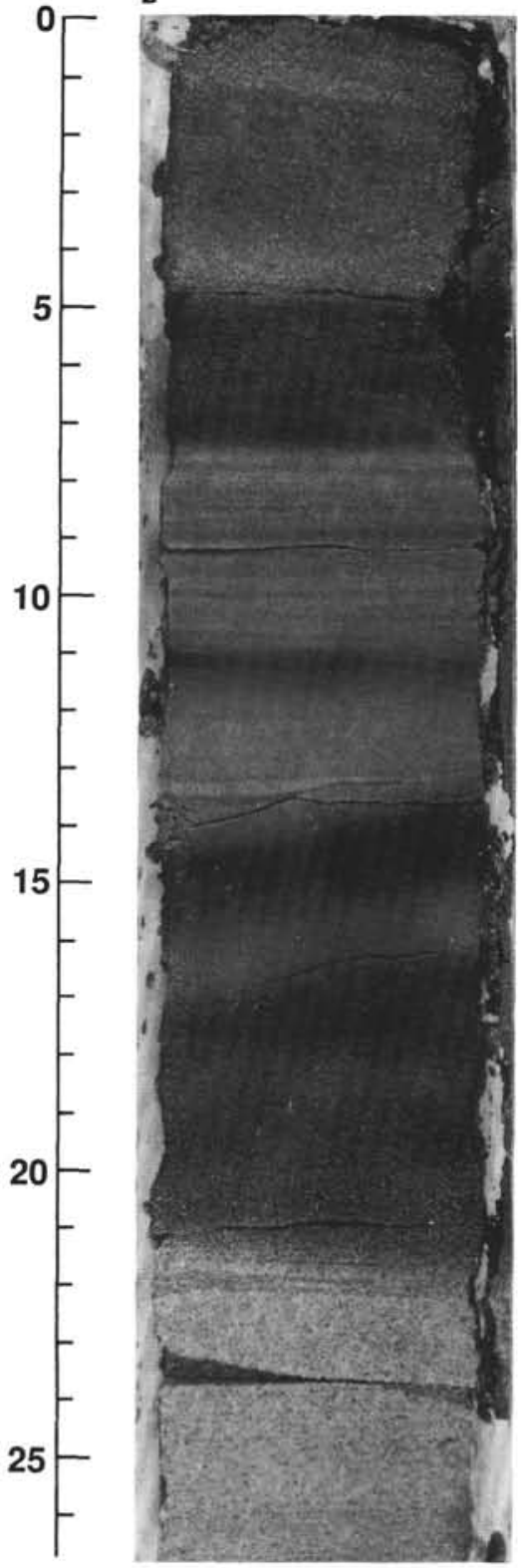

Plate 1. 1. Well defined planar stratification in the overall normally graded, medium-grained blue tuff in Section 127-796B-18R-3. Variation in color corresponds to changes in dominant clast type as a result of density segregation. See text for discussion. 2. Stratification in fine-grained blue tuff defined by normal size-grading and density segregation in Section 127-796B-18R-3. Darker colored layers are more crystal- and lithic-rich compared with lighter colored, vitric fragment-rich layers 

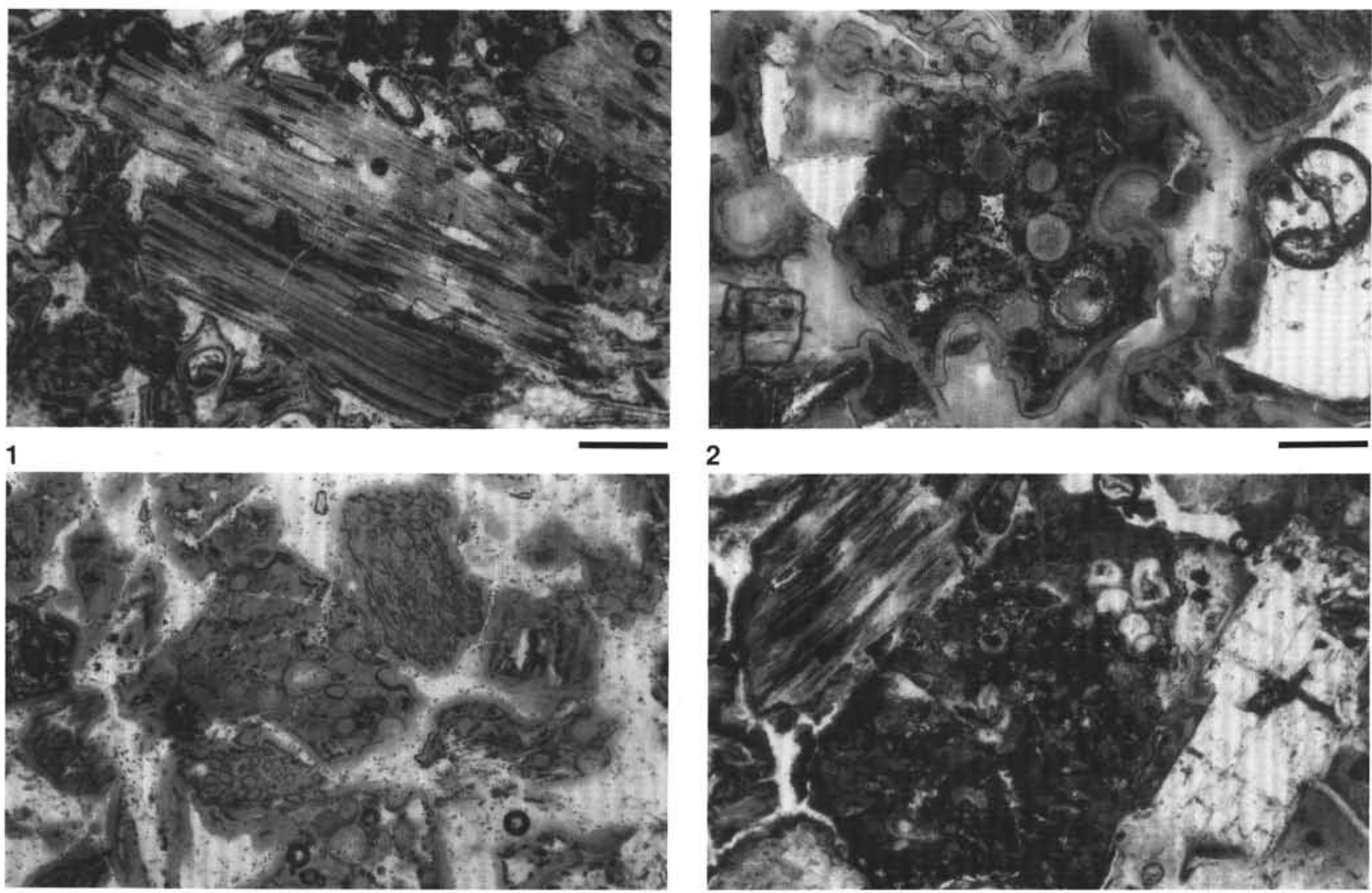

3

\section{4}
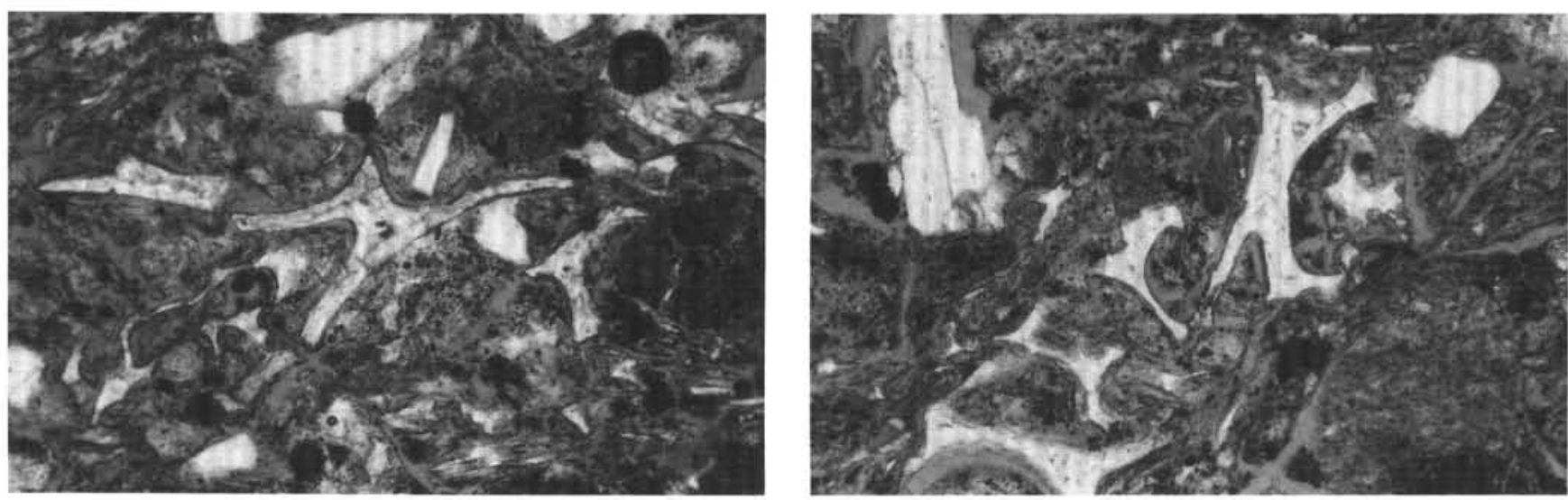

5

6

Plate 2. 1. Long-tube pumice from Sample 127-794B-21R-3, 56-58 cm. Scale bar is $0.25 \mathrm{~mm}$. 2. Vesicular hydroclast from Sample 127-794B-23R-1, 23-25 $\mathrm{cm}$. Note that the margins of the grain transect small vesicles (smaller than the grain). Scale bar is $0.25 \mathrm{~mm}$. 3. Typical vesicular hyaloclasts from Sample 127-794B-23R-CC, $10-12 \mathrm{~cm}$. Scale bar is $0.25 \mathrm{~mm}$. 4. The dominant clast types in the blue tuff at Site 794 are long-tube pumice (upper left), vesicular hydroclast (center), and a euhedral plagioclase crystal (lower right) in Sample 127-794B-21R-6, 16-18 cm. Scale bar is $0.35 \mathrm{~mm}$. 5. Delicate bubble-wall shards and other fragmented material in Sample 127-796B-18R-1,21-23 cm. Scale bar is $0.25 \mathrm{~mm}$. 6. Several bubble-wall shards (center) with vesicle size (based on radius of curvature) significantly larger than the shards themselves in Sample 127-796B-18R-1,21-23 cm. Other common clast types include euhedral plagioclase crystals (upper left) and siliceous claystone rip-up clast (lower right). Scale bar is $0.25 \mathrm{~mm}$. 